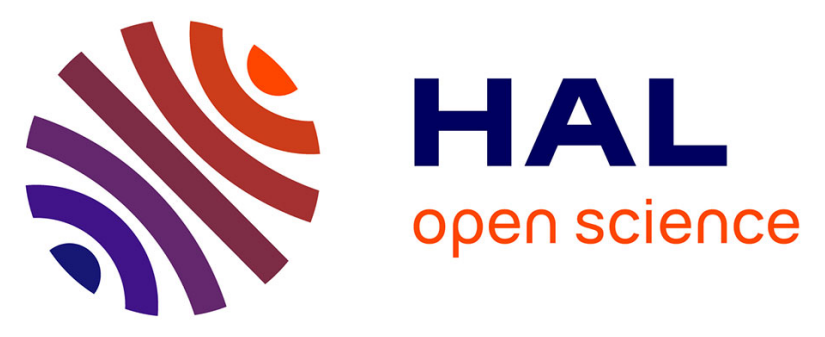

\title{
Effect of milling and sieving processes on the physicochemical properties of okra seed powders
}

Idriss Miganeh Waiss, André Kimbonguila, Fatouma Mohamed Abdoul-latif, Laurette Brigelia Nkeletela, Louis Matos, Joel Scher, Jérémy Petit

\section{- To cite this version:}

Idriss Miganeh Waiss, André Kimbonguila, Fatouma Mohamed Abdoul-latif, Laurette Brigelia Nkeletela, Louis Matos, et al.. Effect of milling and sieving processes on the physicochemical properties of okra seed powders. International Journal of Food Science and Technology, 2020, 55 (6), pp.2517-2530. 10.1111/ijfs.14503 . hal-02882001

\section{HAL Id: hal-02882001 https://hal.science/hal-02882001}

Submitted on 31 Aug 2021

HAL is a multi-disciplinary open access archive for the deposit and dissemination of scientific research documents, whether they are published or not. The documents may come from teaching and research institutions in France or abroad, or from public or private research centers.
L'archive ouverte pluridisciplinaire HAL, est destinée au dépôt et à la diffusion de documents scientifiques de niveau recherche, publiés ou non, émanant des établissements d'enseignement et de recherche français ou étrangers, des laboratoires publics ou privés. 


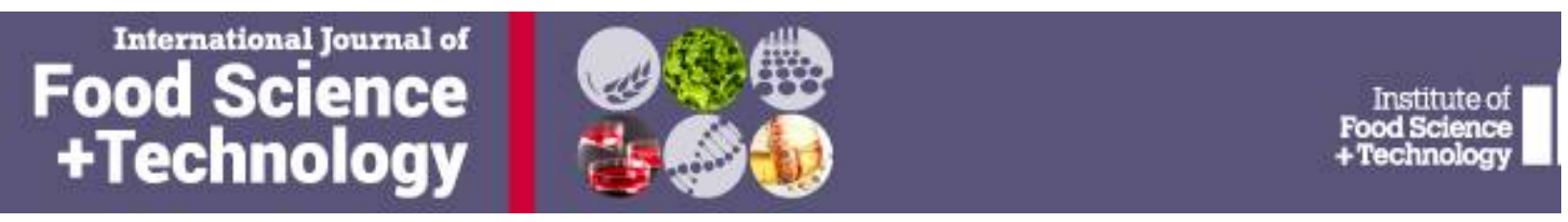

\section{Effect of milling and sieving processes on the physicochemical properties and flow properties of okra powders}

\begin{tabular}{|c|c|}
\hline Journal: & International Journal of Food Science and Technology \\
\hline Manuscript ID & IJFST-2019-28347.R2 \\
\hline Manuscript Type: & Original Manuscript \\
\hline $\begin{array}{r}\text { Date Submitted by the } \\
\text { Author: }\end{array}$ & $\mathrm{n} / \mathrm{a}$ \\
\hline Complete List of Authors: & $\begin{array}{l}\text { WAISS, Idriss; Université Marien Ngouabi Faculté des Sciences de la } \\
\text { Santé, ; Universite de Lorraine, LIBio } \\
\text { KIMBONGUILLA, André; Université Marien Ngouabi Faculté des Sciences, } \\
\text { Laboratoire de Génie des Procédés Industriels } \\
\text { ABDOUL-LATIF, FATOUMA; Université Marien Ngouabi Faculté des } \\
\text { Sciences, Laboratoire de Génie des Procédés Industriels } \\
\text { NKELETELA, Laurette ; Université Marien Ngouabi Faculté des Sciences } \\
\text { de la Santé, Laboratoire de Génie des Procédés Industriels } \\
\text { MATOS, LOUIS ; Université Marien Ngouabi Faculté des Sciences de la } \\
\text { Santé, } \\
\text { Scher, Joël; Universite de Lorraine, LIBio } \\
\text { Petit, Jeremy; Universite de Lorraine, LIBio }\end{array}$ \\
\hline Keywords: & $\begin{array}{l}\text { okra seeds, sieving, particle size, flowability, FT4 powder rhometer, } \\
\text { Milling }\end{array}$ \\
\hline
\end{tabular}

\section{SCHOLARONE $^{\text {M }}$ Manuscripts}




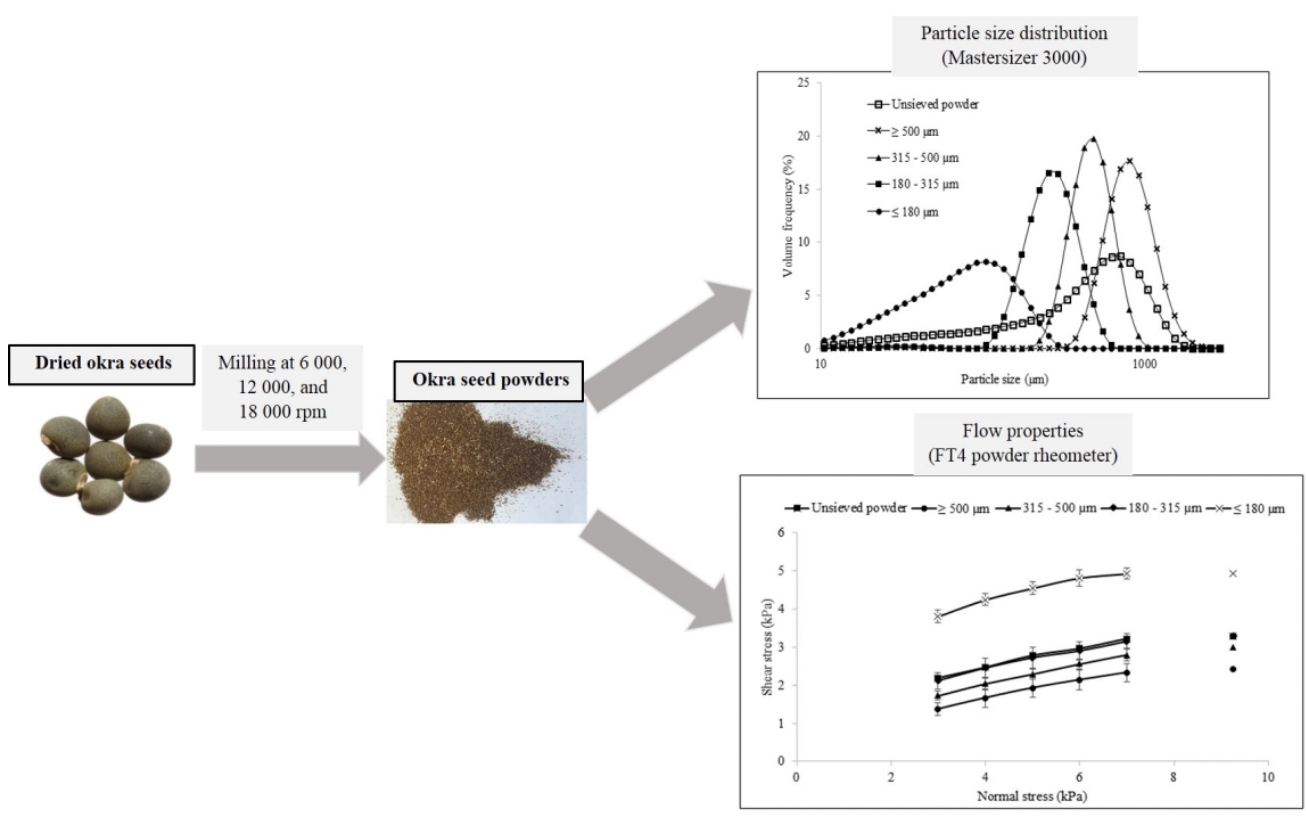

Graphical abstract

$288 \times 177 m m(150 \times 150$ DPI $)$ 
1 Effect of milling and sieving processes on the physicochemical properties and flow properties

2 of okra powders.

3 Idriss MIGANEH WAISS ${ }^{1,2,3}$, André KIMBONGUILA ${ }^{1,2}$, FATOUMA MOHAMED 4 ABDOUL-LATIF ${ }^{3}$, Laurette Brigelia NKELETELA ${ }^{1}$, Louis MATOS ${ }^{1}$, Joël SCHER ${ }^{2}$, Jérémy 5 PETIT $^{2 *}$.

$6 \quad{ }^{1}$ Laboratoire de Génie des Procédés Industriels, Chaire UNESCO - ENSP, Université Marien $7 \quad$ Ngouabi, BP 69, BRAZZAVILLE, Republic of the Congo.

82 Université de Lorraine, LIBio (Laboratoire d'Ingénierie des Biomolécules), F-54000 9 NANCY, France.

$10{ }^{3}$ Institut des Recherches Médicinales, Centre d'Etudes et de Recherches de Djibouti, Route de 11 l'aéroport, BP 486 DJIBOUTI, Djibouti.

* E-mail : jeremy.petit@univ-lorraine.fr

13 Tel: +33 (0)3 72744094 . 
Key words: okra seeds; milling; sieving; particle size; FT4 powder rheometer; flowability

\section{Introduction}

Okra (Abelmoschus Esculentus (L.) Moench) is a vegetable widely grown in tropical and subtropical regions (Torkpo et al., 2009; Jarret et al., 2011). It is called bamia or bamya in some parts of the world, particularly in Asia and the Middle East (Uka et al., 2013). This crop is generally considered as drought-resistant and has fewer pests than soybean (Miller et al., 1949; Jarret et al., 2011). Okra plays an important role in the human diet by supplying carbohydrates, protein, fat, minerals, and vitamins that are usually deficient in staple foods (Adelakun et al., 2009). It is a vegetable with an enormous economic potential for poor communities because of its sales potential in rural and urban markets (Adelakun et al., 2011). Although the seed pods are most often used (Camciuc et al., 1998; Ndangui et al., 2010), mature seeds are known to have superior nutritional quality. (Oyelade et., 2003) reported that okra seed is rich in proteins and lipids. A Nigerian research program initiated by Nigeria reported that dry okra seeds were a good source of proteins (45\%) and fat (34\%) (Oyelade et al., 2003; Adelakun et al., 2009), elassifying it as a nutrient rich plant, which could be used for feeding children and fight against malnutrition. The high nutritional potential of okra seeds was also evidenced. In the Republic of the Congo, research about okra seeds began in 2010 with Ndangui and Kimbonguila Ndangui et al. (2010), who determined the proximate composition of okra seeds ( $24 \%$ proteins, $24 \%$ fat, $36 \%$ carbohydrates), and were concluded that okra have high nutritional potential. The nutritional importance of okra seeds reawakened interest in bringing the crop into commercial production. Although extensive information is available about nutritional quality of okra seeds, no study, to our knowledge, focused on the distribution of nutritional compounds within granulometric classes of okra seed powders produced by milling processes. In fact, it can be hypothesized that large particles may be richer in fibers, which are difficult to grind; hence, small particles may be enriched in minerals, fat, and proteins and have a higher nutritional quality, as previously reported for various plant parts (Becker et al., 2016; Zaiter et al., 2016; Deli et al., 2019a). For this purpose, the current study deals with the production of okra seed powders by successive milling and sieving processes, with the aim to determine if some granulometric classes of okra seeds powder could both have a great nutritional quality and good flow properties_(Adelakun et al., 2011; Chen et al., 2015), making them suitable for the production of food supplements. Milling induces particle size reduction, broadening of particle size distribution, and increases specific surface area, leading to the improvement of material functionalities, especially regarding extraction efficiency and bioavailability of nutritional bioactive compounds (Crayveld et al., 2009; Zhao et al., 2009; Zhang et al., 2012; Zaiter et al., 
2016). The combination of milling and sieving processes could be interesting to identify granulometric classes richer in fat and proteins, generally concentrating bioactive compounds (Brewer et al., 2014; Becker et al., 2016; Lucas-González et al., 2017). This would enable optimizing the extraction of bioactive compounds of plants, by reducing solvent consumption and extraction time (Zaiter et al., 2016; Deli et al., 2019a).

Particle size control seems also interesting with regard to powder flowability Nutritional quality of food powders is not the only criterion for their production at industrial scale, their ability to be transported, handled, and stored is also crucial for their manufacturing. Powder flowability is one of the most important powder technofunctionalities regarding these aspects. Thus, this study intended to evaluate the nutritional quality but also the flowability of granulometric classes of okra seed powders. It has been shown that particle size distribution is a major characteristic controlling the flowability of powders having similar proximate composition (Petit et al., 2017). A decrease in particle size is often associated with an increase in cohesion because the interparticular forces are increased when the distance between particles is reduced owing to higher interparticular surface contact area. So, small particles are generally cohesive and have a poor flowability lower capacity to flow. The major influence of particle size on flow behavior has been recently reported for many powdered foods and food supplements: for instance, foufou and foutou powders (instant plantain-based powders) (Gnagne et al., 2017), Boscia senegalensis, D. glomerata and H. sabdariffa plant powders (Deli et al., 2019b).

Thus, the purpose of the present study was to investigate the nutritional quality on the basis of proximal composition and flow properties (flow energy, compressibility, cohesion, flow factor, etc.) of these powders, as powder flowability is an important functionality for industrial manufacturing, handling, and storage. This was achieved with the FT4 powder rheometer (Freeman Technology) (Gnagne et al., 2017), which provides comprehensive series of methods to characterize powder behavior. In this study, okra seeds were milled with an ultra-centrifugal mill at three rotating speeds: 6000,12000 , and $18000 \mathrm{rpm}$, then the three powder samples were each separated in four granulometric sizes by sieving: $\geq 500 \mu \mathrm{m}, 315$ - $500 \mu \mathrm{m}, 180$ - 315 $\mu \mathrm{m}$, and $\leq 180 \mu \mathrm{m}$. The influence of proximal composition and mean particle size of granulometric classes of okra seed powders on their flowability was investigated, in order to conclude on the impact of successive milling and sieving processes on okra seed powder nutritional quality and flow characteristics.

\section{Material and methods}


101

102

103

104

105

106

107

108

109

110

111

112

113

114

115

116

117

118

119

120

121

122

123

124

125

126

127

128

129

130

131

132

133

\subsection{Material: okra seeds}

Okra seeds were purchased from farmers in Impfondo locality, in the north of the Republic of the Congo $\left(1^{\circ} 37^{\prime} 7.47^{\prime \prime} \mathrm{N} ; 18^{\circ} 3^{\prime} 44.459^{\prime \prime} \mathrm{E}\right)$. Okra were shelled (the seeds were removed from the pods), then seeds were sorted to remove impurities and sun-dried in the open air at $30^{\circ} \mathrm{C}$. Dry seeds were stored at $10{ }^{\circ} \mathrm{C}$ until powder production.

\subsection{Powder production by milling and sieving}

$500 \mathrm{~g}$ sun-dried okra seeds were milled with an ultra-centrifugal mill ZM 200 (Retsch, France) at three different milling speeds $(6000,12000$, and $18000 \mathrm{rpm})$ at room temperature $\left(25^{\circ} \mathrm{C}\right)$ using a $20-\mathrm{cm}$ sieve drilled with 1-mm trapezoidal holes. Then, obtained powder was collected in sealable polyethylene bags before performing sieving.

\subsection{Okra seed powder sieving}

Okra seed powders issued resulting from the milling step were sieved with an Analyzer 3 Spartan sieve shaker (Fritsch, Idar-Oberstein, Germany) with $0.5 \mathrm{~mm}$ vibration amplitude for 24 min using sieves of 180,315 , and $500 \mu \mathrm{m}$ mesh sizes. Hence, the following granulometric classes were produced: $\geq 500 \mu \mathrm{m}, 315$ - $500 \mu \mathrm{m}, 180-315 \mu \mathrm{m}$, and $\leq 180 \mu \mathrm{m}$.

The material on each sieve was collected in sealable polyethylene bags, weighed to determine the mass yield of each granulometric class, and stored at $10{ }^{\circ} \mathrm{C}$ until analysis.

\subsection{Physical properties of okra seed powders: particle size distribution}

The particle size distribution of okra seed powders (unsieved powders and granulometric classes) were determined by laser diffraction granulometry using dry dispersion (Mastersizer 3000, Malvern Instruments France, Orsay, France) at room temperature $\left(25^{\circ} \mathrm{C}\right)$. Dispersion conditions for all powders except the $\leq 180 \mu \mathrm{m}$ powder samples were as follows: $100 \%$ air pressure at 4 bar, $3 \mathrm{~mm}$ hopper gap, and $40 \%$ feed rate. For the $\leq 180 \mu \mathrm{m}$ powder samples, the following dispersion conditions were employed: $100 \%$ air pressure at 4 bar, 4 mm hopper gap, and $70 \%$ feed rate. The chosen size estimator was the equivalent diameter in volume.

The d10, d50, and d90, which are characteristic diameters representative of the particle size distribution, were calculated. They represent the diameters for which $10 \%, 50 \%$ and $90 \%$, respectively, of the particle population have lower sizes. Last, the span was used to evaluate the width of the particle size distribution; it was determined according to the following equation 1 :

Span $=\frac{\mathrm{d} 90-\mathrm{d} 10}{\mathrm{~d} 50}$

\subsection{Powder proximate composition}

The proximate composition of all granulometric classes as well as unsieved powders were evaluated with standard methods. Fat content was determined by Soxhlet method using $5 \mathrm{~g}$ 
powder, hexane as extraction solvent, and $8 \mathrm{~h}$ extraction duration (Castro et al, 1998). Moisture content was measured by weight loss after drying 3 g powder at $103{ }^{\circ} \mathrm{C}$ for $5 \mathrm{~h}$ (AFNOR (Agence Française de NORmalisation), 1976). Ash content was evaluated by incinerating $3 \mathrm{~g}$ powder in a muffle furnace at $550{ }^{\circ} \mathrm{C}$ for $12 \mathrm{~h}$ (ADPI (American Dry Product Institute, Elmhurst, IL), 2002). Total protein content was determined by Kjeldahl method (Bradstreet, 1954). Carbohydrate content was calculated as the difference between $100 \%$ and the contents in other components; the associated standard error was deduced by propagation of uncertainties.

\subsection{Characterization of powder flow properties}

Rheological properties of okra seed powders were measured with the FT4 powder rheometer (Freeman Technology, Worcestershire, UK) using $25 \mathrm{~mm}$ accessories. Measurement test of stability, compressibility, aeration, and shear cell were performed with the standard method of powder rheometer FT4 with some modifications (Gnagne et al., 2017). Detailed descriptions of FT4 standard tests can be found in Freeman (2007) and Leturia et al. (2014).

\subsubsection{Stability test}

The stability test is intended to determine if powder flowability in unconfined (low normal stress) conditions is affected when making the powder flow. Indeed, powder agglomeration, segregation, or attrition may change the energy needed to make the powder flow. Thus, the energy required to make the powder flow was measured in flow conditions imposed by the standard stability test seven times successively by rotating a blade down and up in the conditioned powder bed. Thus, the stability test consists in the succession of test and conditioning cycles. Conditioning was achieved by the gentle displacement of the powder bed by the rotating blade. Conditioning and test cycles were carried out at $100 \mathrm{~mm} / \mathrm{s}$ blade tip speed and the powder sample was loaded into an assembly of two glass cylinders, the powder bed was conditioned and then the upper cylinder was removed to obtain a precise volume $(25 \mathrm{~mL})$ of conditioned powder for tests. From the measurements of force and torque of the blade, various flow parameters can be extracted; the most important were:

- Basic flowability energy (BFE, mJ), defined as the flow energy measured upon downward moving of the blade during test 7.

- Specific energy ( $\mathrm{SE}, \mathrm{mJ} / \mathrm{g})$ ) it defines the energy per gram needed to displace the conditioned powder bed during upward moving of the blade. It represents a measure of how powder flows in a low-stress environment. 
165 - Conditioned bulk density $(\mathrm{CBD}, \mathrm{g} / \mathrm{mL})$, which is a density measurement of the powder bed in conditioned state. It is thus very similar to the classical powder aerated density.

167

168

169

170

171

172

173

174

175

176

177

178

179

180

181

182

183

184

185

186

187

188

189

190

191

192

193

194

195

\subsubsection{Compressibility test}

For the compressibility test, the powder sample was first placed in the measurement cell (i.e. two overlaid $25 \mathrm{~mm} \times 10 \mathrm{~mL}$ glass cylinders) and submitted to three conditioning cycles. After that, the vessel was split to remove any excess powder a1 (Eq. 2) e was replaced by the vented piston. Then, powder was slowly compressed by the vented piston moving vertically at 0.05 $\mathrm{mm} . \mathrm{s}^{-1}$ at different normal stresses ranging from 0.5 to $15 \mathrm{kPa}$, and the percentage change in volume of the powder bed, corresponding to powder compressibility, was measured. Powder compressibility at $15 \mathrm{kPa} \mathrm{CP} 15 \mathrm{kPa}$ was used to calculate compacted density $\left(\mathrm{CD}_{15 \mathrm{kPa}}\right)$, which is the mass of powder per unit volume of the powder bed, including the volume of all interparticle voids (Abdullah and Geldart, 1999) when applying $15 \mathrm{kPa}$ normal stress. $\mathrm{CD}_{15 \mathrm{kPa}}$ was calculated with equation 2 :

$$
\mathrm{CD}_{15 \mathrm{kPa}}=\frac{100}{\left(100-\mathrm{CP}_{15 \mathrm{kPa}}\right) \cdot \mathrm{CBD}}
$$

\subsubsection{Aeration test}

The aeration test is a quick way to evaluate the fluidization ability of a powder. The aeration test consists in introducing air into the powder and evaluating how this changes the flow energy (Freeman, 2007; Leturia et al., 2014; Gnagne et al., 2017). The powder sample was placed in the measurement cell (25 mm x $35 \mathrm{~mL}$ glass cylinder) fitted with a porous plate and three conditioning cycles were carried out to achieve a homogeneous packing state of the powder sample. The aeration test was then performed by measuring the flow energy of the powder bed during downward moving of the blade through the powder bed at $-100 \mathrm{~mm} \cdot \mathrm{s}^{-1}$ tip speed for air velocities ranging from 0 to $5 \mathrm{~mm} \mathrm{~s}^{-1}$ by $0.5 \mathrm{~mm} . \mathrm{s}^{-1}$ steps. Between each test cycle, a conditioning cycle was carried out to obtain a steady state of aerated powder. The most important parameters measured by the aeration test are defined below:

- Aerated energy (AE, mJ), which is the flow energy measured during downward moving of the blade through the powder bed at maximal air velocity $\left(10 \mathrm{~mm} \cdot \mathrm{s}^{-1}\right)$.

- Aeration ratio (AR, dimensionless) that designates the factor by which the basic flowability energy (i.e. at $0 \mathrm{~mm} . \mathrm{s}^{-1}$ air velocity) is reduced when aerating the powder bed at maximal air velocity of $10 \mathrm{~mm} \mathrm{~s}^{-1}$. It was calculated according to equation 3 : 
$197 \quad \mathrm{AR}=\frac{\mathrm{BFE}}{\mathrm{AE}}$

(Eq. 3)

198

199

200

201

202

203

204

205

206

207

208

209

210

211

212

213

214

215

216

217

218

219

220

221

222

223

\subsubsection{Shear cell test}

Shear cell tests are intended to determine the shear stress required to initiate flow in a preconsolidated powder, using a specially designed shear head equipment. This test provides indication of how easily a powder moves from a static state to dynamic flow in confined environments (i.e. at high normal stress). During the FT4 shear cell test, the sample powder is subjected to a pre-consolidation step at $9 \mathrm{kPa}$ normal stress before subsequent shear tests are carried out at normal stresses ranging from 7 to $3 \mathrm{kPa}$ by $1 \mathrm{kPa}$ steps (Freeman, 2007; Yu et al., 2011; Fu et al., 2012), in which the shear stress required to cause failure of the pre-consolidated powder bed (thus making the powder flow) is measured. This succession of shear tests at decreasing applied normal stresses permits to build the yield locus of the normal stress vs. shear stress curve, from which powder flow properties such as flow factor and powder cohesion can be derived.

Cohesion, expressed in $\mathrm{kPa}$, represents the shear stress required to make the powder bed flow in unconfined conditions: indeed, the cohesive interactions between particles must be broken before they can be individually put in motion. Moreover, generally, the higher the interparticular forces, the more the powder bed can be compressed, and the more energy must be supplied to the powder to make it flow.

Flow factor (ffc) is defined as the ratio between the consolidation stress and unconfined yield stress: The larger the ffc value, the better the powder flows (Jenike, 1964; Rhodes, 2008). Powder flow behaviors can be classified as follows (Fu et al., 2012):

ffc $<1$ : not flowing;

$1<$ ffc $<2$ : very cohesive;

$2<$ ffc $<4$ : cohesive;

$4<$ ffc $<10$ : easy flowing;

$10<$ ffc: free flowing.

\subsection{Statistical analysis}


224 All experiments were conducted in triplicate and results were expressed as mean \pm standard 225 deviation. Statistical analysis was performed to a one-factor analysis of variance using Microsoft Excel 2016, significant differences were assessed with Tukey's HSD at a $5 \%$ confidence level with the DSAASTAT add-on.

\section{Results and discussion}

230

231

232

233

234

235

236

237

238

239

240

241

242

243

244

245

246

247

248

249

250

251

252

253

254

\subsection{Impact of milling speed on okra seed powder granulometry}

Particle size distributions of okra seed powders obtained at the three milling speeds (6 000 , 12000 , and $18000 \mathrm{rpm}$ ) are shown in figure 1.

Figure 1

First, it was observed that okra seed powders were constituted of two populations: one of large particles between 200 and $3000 \mu \mathrm{m}$, the other of fine particles between 5 and $200 \mu \mathrm{m}$. This is typical for seed powders obtained by milling, as the different organs of seeds (seed coat, radicle, cotyledon, etc.) differ in hardness, thus resulting in various particle sizes (Chen et al., 2015). Then, the shift to the left of the particle size distribution at higher milling speed shows that it led to smaller particles, as expected. Besides, when the milling speed was increased, the proportion of fine particles raised to the detriment of the proportion of large particles. This shows that some large particles, presumably having elevated hardness, were converted in finer ones at higher milling speed. Also, it can be guessed that the employed ultra-centrifugal mill may not allow decreasing the particle size under $10 \mu \mathrm{m}$, in agreement with equipment specifications.

Moreover, figure 1 confirms the effect of the milling speed on the particle size distribution of okra seed powders. It is worth noting that a more intense milling was also associated to a broader dispersion of the particle size distribution. Indeed, obtained powder was less monomodal when milling speed was increased, as evidenced by the increase in span. This may be indicative of the occurrence of different grinding mechanisms in the employed milling process. From this granulometric analysis, three mesh sizes $(180,315$, and $500 \mu \mathrm{m})$ were chosen for sieving powders into granulometric classes so that each granulometric class represent a significant mass fraction of the unsieved powder.

\subsection{Efficiency of okra seed powder sieving}


255 Before proximate analysis and characterization of flow properties of the powders, the efficiency of the milling and sieving processes for the production of different granulometric classes were verified by weighing powder samples after sieving (Table 1).

\section{Table 1}

Table 1 shows that the sieving process allowed an efficient fractionation of okra seed powders into the different granulometric classes, as significant mass yields (generally above $10 \%$ ) were found for all sieved powders. As expected from particle size distributions of unsieved powders (figure 1), the $\geq 500 \mu \mathrm{m}$ granulometric class was the most represented (around $50 \%$ mass yield) whatever the milling speed. This is consistent with the fact that seeds are material of rather high hardness, making them difficult to grind, and resulting into powders containing a marked proportion of large particles.

\subsection{Particle size distribution}

Particle size distribution of all granulometric classes and unsieved powder are displayed in figures 2, 3, and 4 and associated granulometric parameters (d10, d50, d90, and span) are presented in table 2 .

Figure 2

\section{Figure 3}

Figure 4

Figures 2, 3, 4 and table 2 show that okra seed powders were correctly fractionated by sieving despite their rather large fat content (that will be discussed in the following subsection 3.4) likely to make them sticky. Indeed, particle size distributions of sieved powders were generally monomodal, with small span values (except for $\leq 180 \mu \mathrm{m}$ granulometric classes whatever the milling speed and the 180 - $315 \mu \mathrm{m}$ granulometric class at $12000 \mathrm{rpm}$ milling speed).

The large width of particle size distributions (span) of $\leq 180 \mu \mathrm{m}$ granulometric classes whatever the milling speed and of the $180-315 \mu \mathrm{m}$ granulometric class at $12000 \mathrm{rpm}$ milling speed may be explained by the presence of numerous fine particles (likely coming from the attrition of larger particles in the course of the milling process) that may adhere to larger ones and thus may be difficult to separate into individual particles. Indeed, as it will be evidenced in the next subsection (3.4) by proximate composition results, okra seed powders were rich in fat, which may favor powder cohesion and result in their agglomeration during the milling process, especially for fine particles, as they had a higher specific surface area and contained more fat. 
286 Whatever it may be, the results of sieve fractionation (table 1) and particle size characteristics 287 of powder fractions (table 2) showed that the successive milling and sieving procedure was 288 effective in micronizing okra seeds and separating unsieved powders into sufficiently different size classes. Indeed, the d50 of sieved powders (granulometric classes) was systematically 290 found between the mesh sizes of upper and lower sieves, which confirms the suitability of sieve shaking for separating okra seed powders.

Milling speed contributed to reduce mean particle size and span of granulometric classes (cf. 293 figures 2, 3, and 4 and table 2), as expected. Both the decrease in particle sizes and the increase in the width of the particle size distribution at higher milling speed were consistent with the more elevated mass fractions of $\leq 180 \mu \mathrm{m}, 180-315 \mu \mathrm{m}$, and $315-500 \mu \mathrm{m}$ granulometric classes (table 1).

\subsection{Proximate composition}

In table 3, contents in moisture, fat, proteins, ash, and carbohydrates of all granulometric classes 300 and unsieved powders of okra seeds were evaluated to investigate the influence of milling speed and sieving efficiency. Indeed, proximate composition may be indicative of the stickiness of powder surface (for instance, surface fat generally tend to increase powder stickiness) (Langrish et al., 2006; Viviane et al., 2007), which is known to greatly impair powder flowability.

\section{Table 3}

305

306

307

308

309

310

311

312

313

314

315

316

317

Moisture content of granulometric classes $\leq 180 \mu \mathrm{m}, 180-315 \mu \mathrm{m}$, and $315-500 \mu \mathrm{m}$ was lower than $10 \%$, whereas unsieved powders and $\geq 500 \mu \mathrm{m}$ samples had a moisture content ranging between 10 and $13 \%$. It is generally considered that a moisture content lower than 10 $\%$ ensures powder stability during storage (Kaur, Kaushal and Sandhu, 2013). Then, granulometric classes composed of smaller particles were expected to have better preservation abilities than unsieved powders and $\geq 500 \mu \mathrm{m}$ samples. Also, fat and protein contents significantly decreased when the particle size was increased, unlike carbohydrates and ash that increased. As regards the influence of milling speed, it appeared that the contents in fat and proteins (resp., carbohydrates and ash) decreased (resp., increased) in $\leq 180 \mu \mathrm{m}$ and $180-315$ $\mu \mathrm{m}$ granulometric classes and increased (resp., decreased) in $315-500 \mu \mathrm{m}$ and $\geq 500 \mu \mathrm{m}$ granulometric classes. Indeed, it was expected that a more intense milling enhances the size reduction of plant material and thus the release of fat and proteins from plant cells (Becker et al., 2016; Zaiter et al., 2016). This can be related to okra seed structure: indeed, the outer shell 
is composed of a higher proportion of fibers than other parts of okra seeds. Then, as fibers are more difficult to grind, larger particles may be enriched in this component, leading to higher carbohydrate content. Consequently, the proportions of fat and proteins were decreased in larger particles. Previous studies explained that plant parts containing a high proportion of fibers and sugars (both belonging to carbohydrates) are harder to grind and thus result in larger particles after milling, whereas plant parts with higher levels of fat and proteins are easier to grind and thus lead to smaller particles (Becker et al., 2016; Zaiter et al., 2016). So, proximate composition of okra seed powders was greatly dependent on granulometric class; in other words, the mean particle size had a marked impact on proximate composition of okra powders. The moisture content was decreased for powder samples constituted by small particles, because they probably undergo a higher friction-induced heating during milling. Moreover, statistical analysis permitted to show that large particles were richer in carbohydrates. Plant parts containing a large proportion of fibers are expected to be more difficult to grind and result in large particles. As fibers were included in total carbohydrates in the proximate composition analysis, the larger content in carbohydrates of higher size granulometric classes of okra seed powders may be due to a higher proportion of fibers. Bioactive compounds are often associated with proteic and fatty fractions, thus the smaller granulometric classes of okra seeds are expected to have higher contents in bioactive compounds (Becker, et al 2016; Deli, Ndjantou, et al., 2019). At higher milling speed, this differential distribution of macronutrients within granulometric classes was enhanced: small particles contained even more proteins and fat and less moisture, carbohydrates, and ashes. Thus, the discriminating power of the sieving process in matter of proximate composition was improved at higher milling speed.

\subsection{Flow properties of okra seed powders}

\subsubsection{Stability and compressibility tests}

The results of stability tests for granulometric classes and unsieved samples of okra seed powders are presented in table 4.

Table 4

Whatever the milling speed, unsieved powders presented significant differences with granulometric classes in terms of BFE and SE. Moreover, the CBD of unsieved powders was systematically found within the range of $\mathrm{CBD}$ of granulometric classes. The CBD of granulometric classes decreased with particle size, indicating that the powder bed was less compact for samples composed of smaller particles. This could be an indication of higher 
350 cohesion of smaller granulometric classes, which is consistent with their probable stickiness deriving from their higher fat content as well as with the fact that smaller particles are able to establish more contact points with their surrounding environment (particles, walls), thus impairing their flowability. At first glance, BFE results seemed in contradiction with this conclusion, as BFE decreased with mean particle size and this could be interpreted as better flowability of granulometric classes of smaller mean particle size. However, it should be mentioned that powder bed with poor flow properties may also lead to low BFE values when particle cohesion is so high that the blade only makes flow the small amount of powder located in its vicinity (Leturia et al., 2014; Gnagne et al., 2017). Also, interpretations of powder flowability on the basis of the BFE values may be distorted by important CBD differences. Indeed, the stability test is performed to evaluate the flowability of a given volume of conditioned powder bed, hence sample mass may vary between samples according to aerated density (i.e. CBD) differences. When comparing powder sample differing in CBD, the SE seems more appropriate to give information on powder flowability, as it corresponds to flow energy normalized against powder mass. All okra seed powders exhibited SE values close to 5 $\mathrm{mJ} / \mathrm{g}$, indicating that studied powders had correct flow properties. For samples milled at 6000 $\mathrm{rpm}$, the lower SE (indicative of better flowability) was found for the $180-315 \mu \mathrm{m}$ granulometric class, while at 12000 and $18000 \mathrm{rpm}$ milling speed, the best flow properties on the basis of the SE was found for the highest granulometric class. This is consistent with the fact that larger particles are expected to flow more easily (Petit et al., 2017; Shi et al., 2018). Also, the better flowability of the $180-315 \mu \mathrm{m}$ granulometric class for samples milled at 6000 rpm may result from the lower span of this sample (cf. table 2).

Moreover, the influence of milling speed on powder flowability can be deduced by comparing unsieved powders. Table 4 shows that the SE and the CBD increased, while the BFE decreased, when the milling speed was increased. This trend was expected, because when the milling speed increases, the mean particle size decreases and the interparticular interactions become so high that powders are much cohesive and have a poorer flowability.

Table 4 and figures 5, 6, and 7 present the results of the compressibility tests. Whatever the milling speed, compressibility markedly decreased with mean particle size, as expected: indeed, it has previously been discussed that smaller particles are generally more cohesive, making them more compressible. This confirms the better flow properties of powders composed of larger particles. Unsieved powders had intermediate compressibility, comprised in the range of compressibilities of granulometric classes. Compressibility of unsieved powders and 
383

384

385

386

387

388

389

390

391

392

393

394

395

396

397

398

399

400

401

402

403

404

405

406

407

408

409

410

411

412

413

granulometric classes was increased at higher milling speed, consistently with the lower mean particle size, and this was expected to lower powder flowability.

Final densities after compression at $15 \mathrm{kPa} \mathrm{CD}_{15 \mathrm{kPa}}$ ranged between 0.5 and $0.7 \mathrm{~g} / \mathrm{mL}$ for all powders, and these rather elevated values confirmed that the flowability of studied powders was between correct and good. All these interpretations of compressibility results were valid whatever the applied normal stress (cf. figures 5, 6, and 7).

Figure 5

Figure 6

Figure 7

\subsubsection{Aeration and shear cell tests}

Aeration results of granulometric classes and unsieved samples of okra seed powders are presented in table 5 .

Table 5

All investigated okra seed powders were not fluidizable in standard conditions of the FT4 aeration test (air velocity up to $10 \mathrm{~m} . \mathrm{s}^{-1}$ ). Indeed, very low aeration ratios AR and elevated aerated energies AE were found, showing that the fluidized state was not achieved at maximal air velocity employed in the standard FT4 test. This may be explained by the high mean particle size of $180-315 \mu \mathrm{m}, 315-500 \mu \mathrm{m}$, and $\geq 500 \mu \mathrm{m}$ granulometric classes and the presumed relatively high cohesion of $\leq 180 \mu \mathrm{m}$ and 180 - $315 \mu \mathrm{m}$ granulometric classes (Gnagne et al., 2017; Petit et al., 2017). The low fluidizability of studied powders may constitute an advantage for handling purposes at industrial scale, as loss of these powders by projection in the surrounding air may be reduced. Aeration properties seemed not to be affected by changing the milling speed, which is logical, as the order of magnitude of mean particle size of powder samples was the same whatever the milling speed.

Shear test results are displayed in table 5 and figures 8, 9, and 10. Whatever the milling speed, the flow factor decreased when decreasing the mean particle size of granulometric classes, consistently with the increase in powder cohesion. Indeed, smaller particles are expected to be more cohesive (more interparticular contact points) and thus flow more poorly. Investigated powders ranged from cohesive to easy-flowing, according to Jenike classification (Jenike, 1964). Besides, the trends of decrease in flow factor and increase in cohesion at higher milling 
414 speed were in agreement with the decreased mean particle size of unsieved powders. The results 415 of the shear test met those of stability and compressibility tests, as powders with lower mean 416 particle size needed more energy to flow and were more compressible. This permits to state that 417 in our study the shear cell and compressibility tests were most suitable for sorting powders on 418 the basis of their flowability.

Figure 8

Figure 9

Figure 10

\section{Conclusion}

The objective of this work was to determine the impact of particle size class of okra seed powders on their proximate composition and their flowability. Three different milling speeds were used to produce powders that were each separated in four granulometric sizes by sieving. It was found, as expected, that the mean particle size decreased when the milling speed was increased. The sieving process was successful in separating unsieved powders into sufficiently different size classes: a significant mass yield (generally above $10 \%$ ) was obtained for each sieved powder. Mean particle size was found to be comprised between the upper and lower sieves, confirming the efficiency of the sieving process. A strong correlation was found between mean particle size and proximate composition: more proteins and fat and less water, carbohydrates, and minerals were obtained for smaller granulometric classes. Also, the influence of milling speed and mean particle size of sieved powders on flow properties was denoted. Most samples were cohesive or easy-flowing. $\leq 180 \mu \mathrm{m}$, granulometric classes, having a lower mean particle size and a higher fat content, were significantly more compressible and cohesive than other samples. This information regarding the influence of milling speed and mean particle size on flow properties of okra seed powders should be useful for the production at industrial scale of okra seed powders, especially for handling, packaging, and storage purposes. A compromise should be found between content in nutritional quality and/or content in bioactive compounds, mass yields of the successive milling and sieving processes, and flow properties.

\section{Acknowledgements}

We would like to thank Dr. Florentin MICHAUX, Dr. Jennifer BURGAIN, Pr. Stéphane DESOBRY and Dr. Jordane JASNIEWSKI for their scientific advices. A special thanks should especially be addressed to Carole PERROUD and Carole JEANDEL for technical help regarding powder production and analyses. 
447

448

449

450

451

452

453

454

455

456

457

458

459

460

461

462

463

464

465

466

467

468

469

470

471

472

473

474

475

476

477

478

479

480

481

482

483

484

485

486

487

488

The authors acknowledge also support of the LIBio by the "Impact Biomolecules" project of the "Lorraine Université d'Excellence"(Investissements d'avenir - ANR).

\section{References}

Abdullah, E. C. \& Geldart, D. (1999). The use of bulk density measurements as flowability indicators. Powder Technology, 102, 151-165.

Adelakun, O.E., Oyelade, O.J., Ade-Omowaye, B.I.O., Adeyemi, I.A., M. Van de Venter. (2009). Mineral composition and the functional attributes of Nigerian okra seed (Abelmoschus esculentus Moench) flour. Food and Chemical Toxicology. Elsevier Ltd, 47,1123-1126. doi: 10.1016/j.foodres.2011.08.003.

Adelakun, O. E. \& Oyelade, O. J. (2011). Potential use of Okra Seed (Abelmoschus Esculentus Moench): Flour for Food Fortification and Effects of Processing. Flour and Breads and their Fortification in Health and Disease Prevention. Chapitre 19, 205-2012. doi: 10.1016/B978-012-380886-8.10019-4.

ADPI (American Dry Product Institute, Elmhurst, IL). Determination of total ash in standards for grades of dry milks including methods of analysis, Bulletin 916' (2002). Annual Reviews, 40-41.

AFNOR (Agence Française de NORmalisation), Détermination de la teneur en eau-méthode par étuvage' (1976), ((No: V04 - 348).).

Becker, L., Zaiter. A., Petit. J., Zimmer.D., Karam M.C., Baudelaire. E., Scher. J., Dicko A., (2016). Improvement of antioxidant activity and polyphenol content of Hypericum perforatum and Achillea millefolium powders using successive grinding and sieving, Industrial Crops and Products. Elsevier B.V., 87, 116-123. doi: 10.1016/j.indcrop.2016.04.036.

Bradstreet, R. B. (1954). Kjeldahl Method for Organic Nitrogen', Analytical Chemistry, 26, 185-187. doi: 10.1021/ac60085a028.

Brewer, L. R. Kubola, J. Siriamornpun, S. HeraldT, J. Shi,Y. C. (2014). Wheat bran particle size influence on phytochemical extractability and antioxidant properties. Food Chemistry. Elsevier Ltd, 152, 483-490. doi: 10.1016/j.foodchem.2013.11.128.

Camciuc, M., Deplagne, M., Vilarem., G. Gaset, A., (1998). Okra - Abelmoschus esculentus L. (Moench.) a crop with economic potential for set aside acreage in France. Industrial Crops and Products. Elsevier, 7. 257-264. doi: 10.1016/S0926-6690(97)00056-3.

Castro, M. D. \& Garcia-Ayuso, L. E. (1998). Soxhlet extraction of solid materials : an outdated technique with a promising innovative future. ANALYTICA CHIMICA ACTA, 369, 1-10.

Chen, Y., Zhang, B. C., Sun, Y. H., Zhang, J.G., Sun, H. J., Wei, Z. J., (2015). Physicochemical properties and adsorption of cholesterol by okra (Abelmoschus esculentus) powder. Food and Function. Royal Society of Chemistry, 6, 3728-3736. doi: 10.1039/c5fo00600g.

Crayveld, V., Holopainen, U., Selinheima, E., Kaisa, P., Delcour, J. A., Courtin, C. M. (2009). Extensive Dry Ball Milling of Wheat and Rye Bran Leads to in Situ Production of Arabinoxylan Oligosaccharides through Nanoscale Fragmentation. Journal of Agricultural and Food Chemistry, 57, 8467-8473. doi: 10.1021/jf901870r.

Deli, M., Petit, J., Nguimbou, R. M., Beaudelaire, E., Njintang, Y. N., Scher, J. (2019a). Effect of sieved fractionation on the physical, flow and hydration properties of Boscia senegalensis Lam., Dichostachys glomerata Forssk. and Hibiscus sabdariffa L. powders. Food Science and 
489

490

491

492

493

494

495

496

497

498

499

500

501

502

503

504

505

506

507

508

509

510

511

512

513

514

515

516

517

518

519

520

521

522

523

524

525

526

527

528

529

530

531

Biotechnology. Springer Singapore, 22, 1-15. doi: 10.1007/s10068-019-00597-6.

Deli, M., Baudelaire, E., Metsagang, J.T., N. Petit, J., Njintang, Y. N., Scher, J. (2019b). Successive grinding and sieving as a new tool to fractionate polyphenols and antioxidants of plants powders: Application to Boscia senegalensis seeds, Dichrostachys glomerata fruits, and Hibiscus sabdariffa calyx powders. Food Science and Nutrition, 7, 1795-1806. doi: 10.1002/fsn3.1022.

Freeman, R. (2007). Measuring the flow properties of consolidated, conditioned and aerated powders - A comparative study using a powder rheometer and a rotational shear cell. Powder Technology, 174, 25-33. doi: 10.1016/j.powtec.2006.10.016.

Fu, X., Huck, D., Makein, L., Armstrong, B., Willen, U., Freeman, T. (2012). Effect of particle shape and size on flow properties of lactose powders. Particuology. Chinese Society of Particuology, 10, 203-208. doi: 10.1016/j.partic.2011.11.003.

Gnagne, E. H., Petit, J., Gaiani, C., Scher, J., Amani, G. N.., (2017). Characterisation of flow properties of foutou and foufou flours, staple foods in West Africa, using the FT4 powder rheometer. Journal of Food Measurement and Characterization. Springer US, 11, pp. 11281136. doi: 10.1007/s11694-017-9489-2.

Jarret, R. L., Wang, M. L., \& Levy, I. J. (2011). Seed oil and fatty acid content in okra (Abelmoschus esculentus) and related species. Journal of Agricultural and Food Chemistry, 59, 4019-4024. doi: 10.1021/jf104590u.

Jenike, A. W. (1964). Storage and Flow of Solids. Bulletin of the University of Utah, 53, p. 209. doi: $10.2172 / 5240257$.

Kaur, M., Kaushal, P., and Sandhu, K. S., (2013). Studies on physicochemical and pasting properties of Taro (Colocasia esculenta L.) flour in comparison with a cereal, tuber and legume flour. Journal of Food Science and Technology, 50, pp. 94-100. doi: 10.1007/s13197-0100227-6.

Langrish, T. A. G., Marquez, N., \& Kota, K. (2006). An investigation and quantitative assessment of particle shape in milk powders from a laboratory-scale spray dryer. Drying Technology, 24, 1619-1630. doi: 10.1080/07373930601031133.

Leturia, M., Benali, M.,Lagarde, S., Ronga, I., Saleh, K. (2014). Characterization of fl ow properties of cohesive powders : A comparative study of traditional and new testing methods. Powder Technology. Elsevier B.V., 253, 406-423. doi: 10.1016/j.powtec.2013.11.045.

Lucas-González, R., Viuda-Martos, M., Pérez-Álvarez, J. Á., Fernández-López, J., (2017). Evaluation of Particle Size Influence on Proximate Composition, Physicochemical, TechnoFunctional and Physio-Functional Properties of Flours Obtained from Persimmon (Diospyros kaki Trumb.) Coproducts. Plant Foods for Human Nutrition. 72, 67-73. doi: 10.1007/s11130016-0592-z.

Miller, J.C. Wilson, W.F \& Meadows, M. (1949). Growing okra seed for its oil. Chemurg. Dig, $\mathbf{8}, 22-24$.

Ndangui, C. B. Kimbonguila, A. Nzikou, J. M. Matos, L. Pambou-Tobi, N. P. G. Abena, A. A. Silou, Th. Scher, J. Desobry, S. (2010). Nutritive Composition and Properties Physico-chemical of gumbo (Abelmoschus esculentus L.) Seed and Oil. Research Journal of Environmental and Earth Sciences, 2, 49-54.

Oyelade, O. J., Ade-Omowaye, B. I. O., and Adeomi, V. F. (2003). Influence of variety on 
532 protein, fat contents and some physical characteristics of okra seeds. Journal of Food 533 Engineering, 57,111-114. doi: 10.1016/S0260-8774(02)00279-0.

534 Petit, J., Burgain, J., Gainani, C. \& Scher, J. (2017). Aptitude à l'écoulement de poudres alimentaires: impact des propriétés physicochimiques des particules. Industries alimentaires et 536 agricoles(IAA), pp. 26-30.

537 Shi, H., Mohanty, R., Chakravarty, S., Cabiscol, R., Morgeneyer, M., Zetzener, H. O., Jin Y., 538 Kwade, A., Luding, S., Magnanimo, V. (2018). Effect of particle size and cohesion on powder 539 yielding and flow. KONA Powder and Particle Journal, 14, 226-250. doi: $540 \quad 10.14356 /$ kona.2018014.

541 Torkpo, S., Danquah, E.Y., Offei, S. K., Blay, E.T. (2009). Esterase, total protein and seed 542 storage protein diversity in Okra (Abelmoschus esculentus L. Moench). West African Journal 543 of Applied Ecology, 9, 1-7. doi: 10.4314/wajae.v9i1.45677.

544 Uka, U., Chukwuka, K. \& Iwuagwu, M. (2013). Relative effect of organic and inorganic 545 fertilizers on the growth of okra [Abelmoschus esculentus (L.) Moench]. Journal of 546 Agricultural Sciences, Belgrade, 58,159-166. doi: 10.2298/jas1303159u.

547 Viviane, S., Birchal, M., Laura, P., Glória, R. S., Wildhagen, A. S., Mujumdar. (2007). Effect 548 of Spray-Dryer Operating Variables on the Whole Milk Powder Quality. Drying Technology, 549 23, 611-636. doi: 10.1081/DRT-200054153.

550 Yu, W., Muteki, K., Zhang, L., \& Kim, G. (2011). Prediction of bulk powder flow performance 551 using comprehensive particle size and particle shape distributions. Journal of Pharmaceutical 552 Sciences. Elsevier Masson SAS, 100, 284-293. doi: 10.1002/jps.22254.

553 Zaiter, A., Becker, L., Petit, J., Zimmer, D., Karam, M. C., Baudelaire, E., Scher, J., Dicko, A.. 554 (2016). Antioxidant and antiacetylcholinesterase activities of different granulometric classes of 555 Salix alba (L.) bark powders. Powder Technology. Elsevier B.V., 301, 649-656. doi: 556 10.1016/j.powtec.2016.07.014.

557 Zhang, Z., Song, H., Peng, Z., Luo, Q., Ming, J., Zhao, G. (2012). Characterization of stipe and 558 cap powders of mushroom (Lentinus edodes) prepared by different grinding methods. Journal 559 of Food Engineering. Elsevier Ltd, 109, 406-413. doi: 10.1016/j.jfoodeng.2011.11.007.

560 Zhao, X., Yang, Z., Gai, G., Yang, Y. (2009). Effect of superfine grinding on properties of 561 ginger powder. Journal of Food Engineering. Elsevier Ltd, 91, 217-222. doi: 562 10.1016/j.jfoodeng.2008.08.024. 


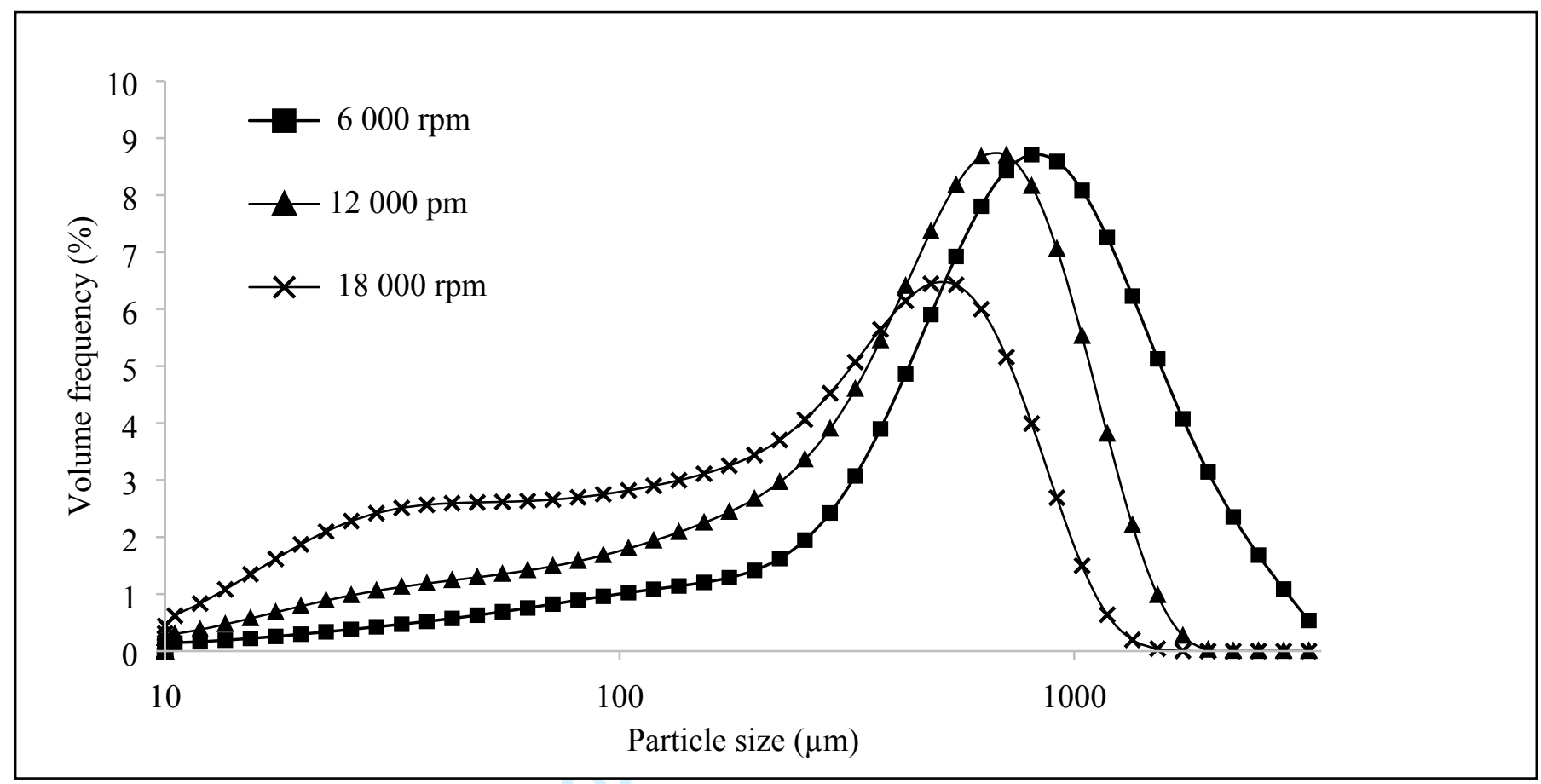

Figure 1: Particle size distributions of okra seed unsieved powders obtained at 6000,12000 , and $18000 \mathrm{rpm}$ milling speed. 


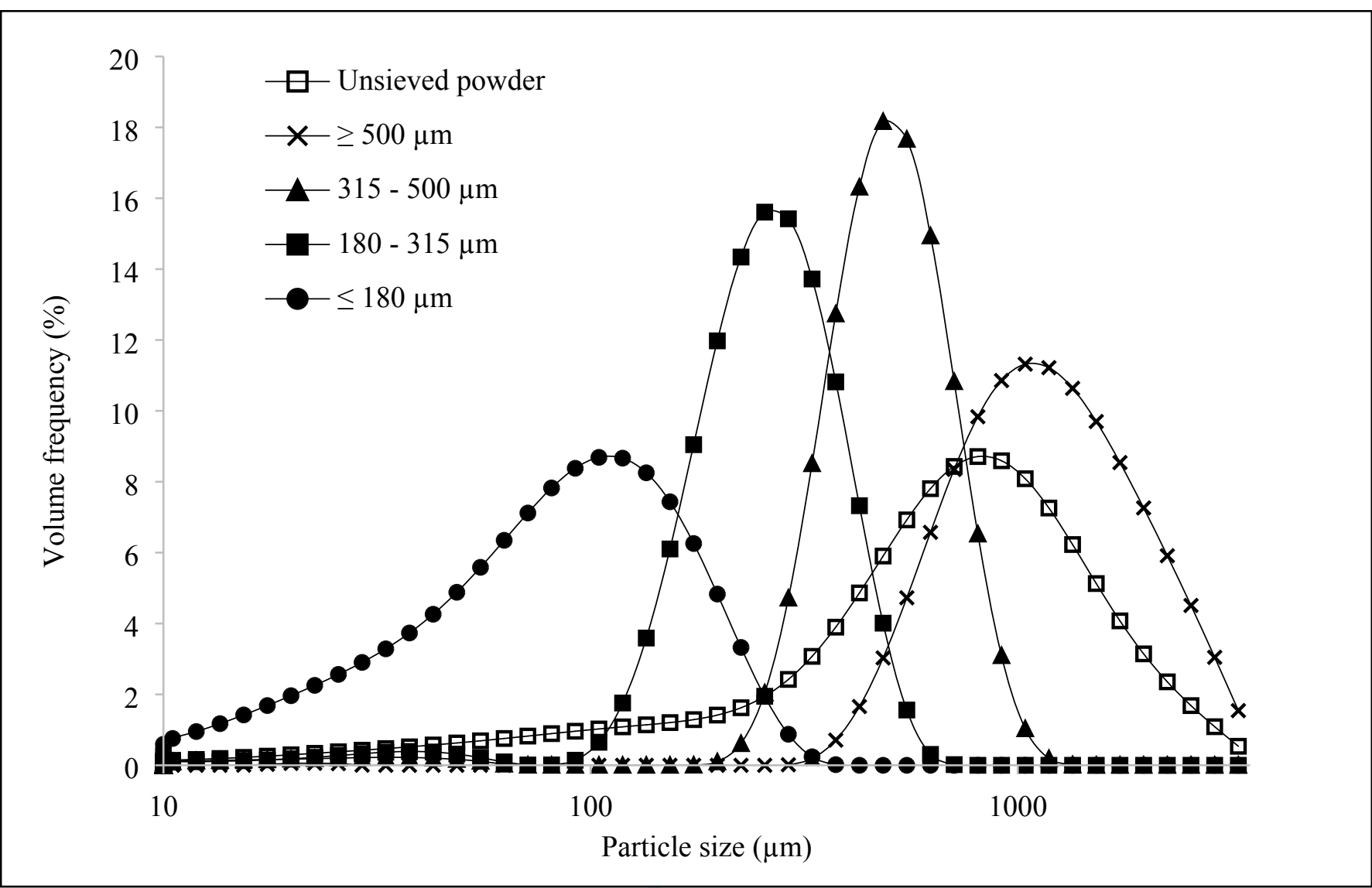

Figure 2: Particle size distributions of the different granulometric classes and unsieved sample of okra seed powders obtained by milling at $6000 \mathrm{rpm}$. 


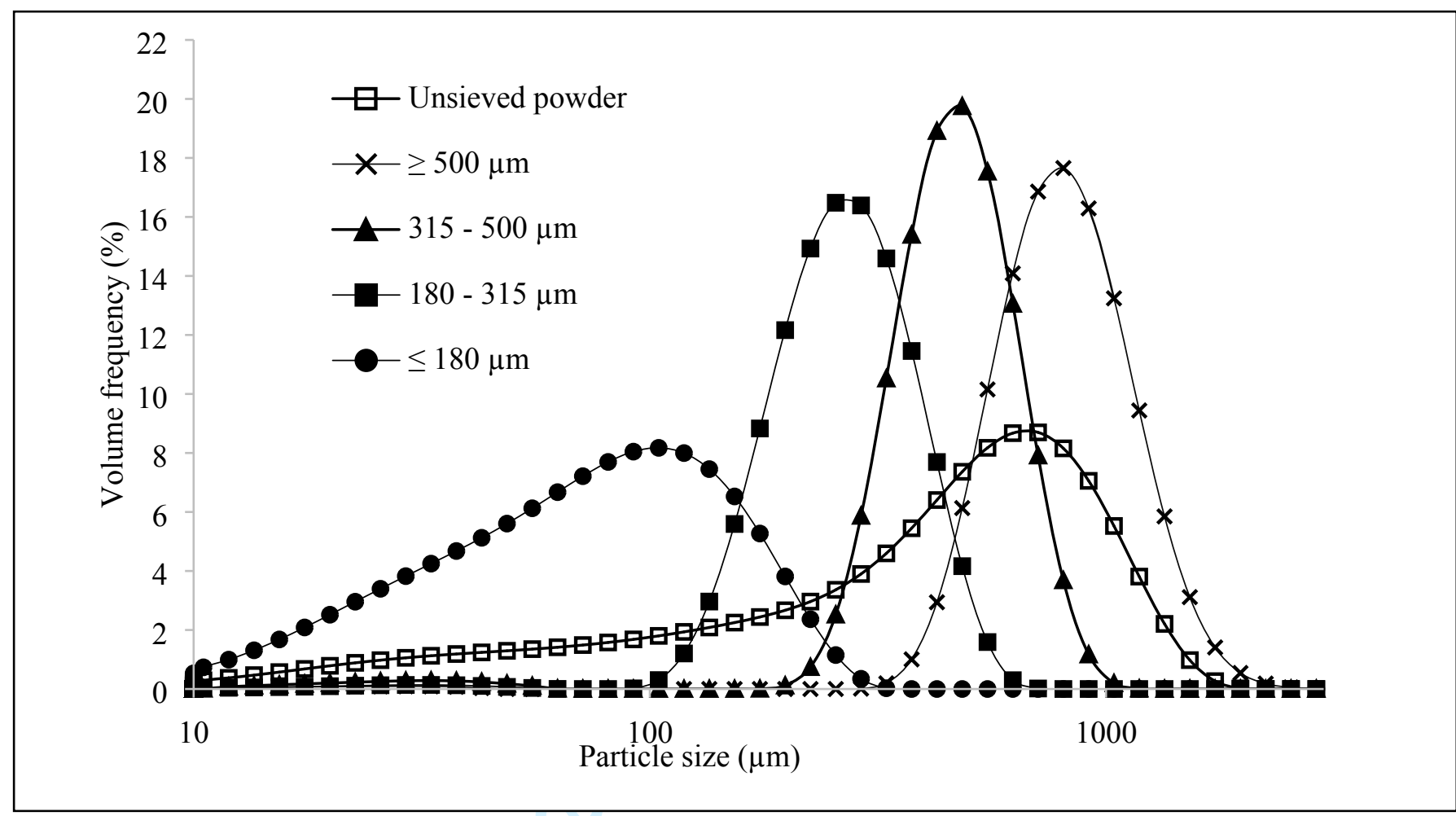

Figure 3: Particle size distributions of the different granulometric classes and unsieved sample of okra seed powders obtained by milling at $12000 \mathrm{rpm}$. 


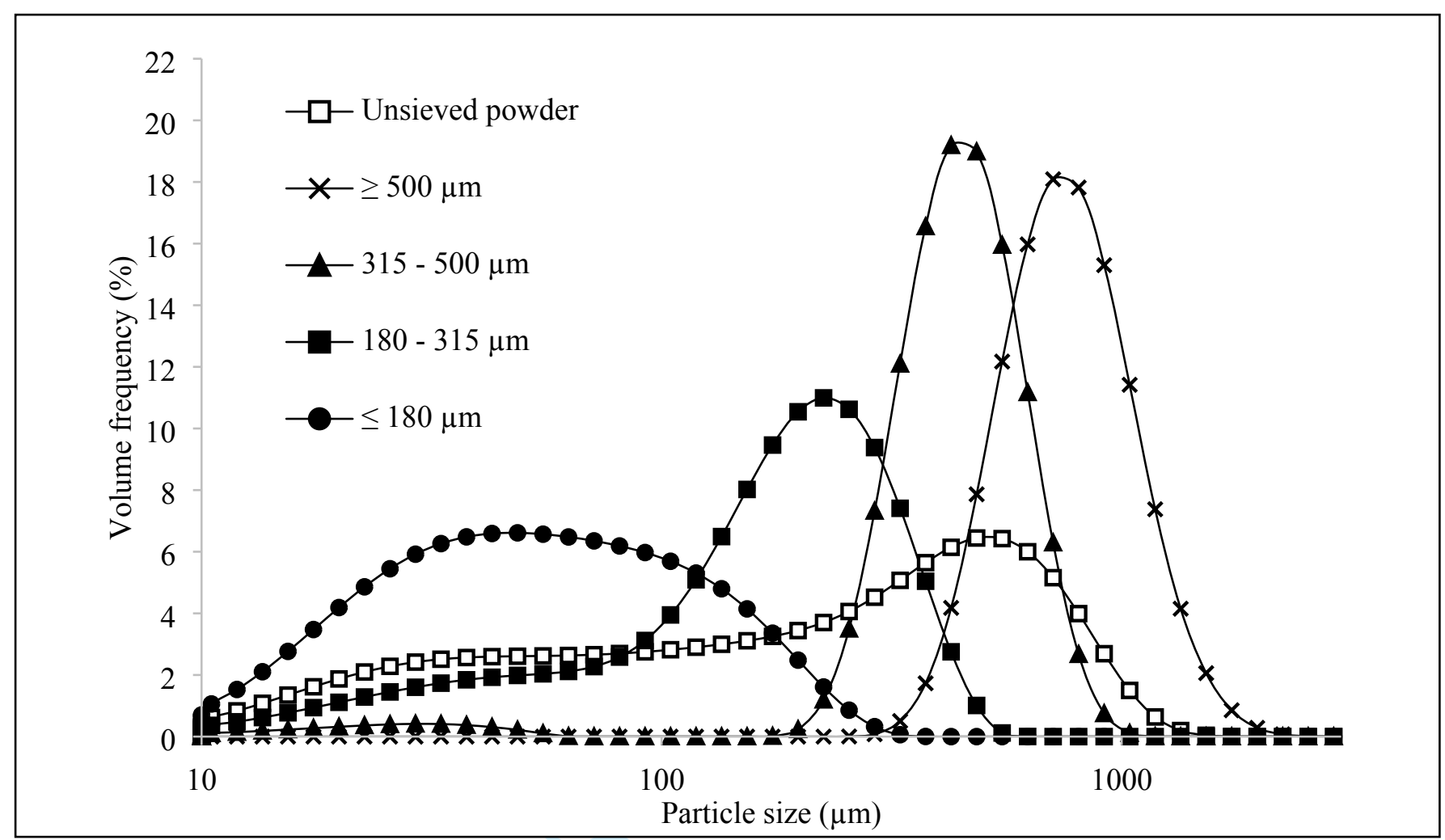

Figure 4: Particle size distributions of the different granulometric classes and unsieved sample of okra seed powders obtained by milling at $18000 \mathrm{rpm}$. 


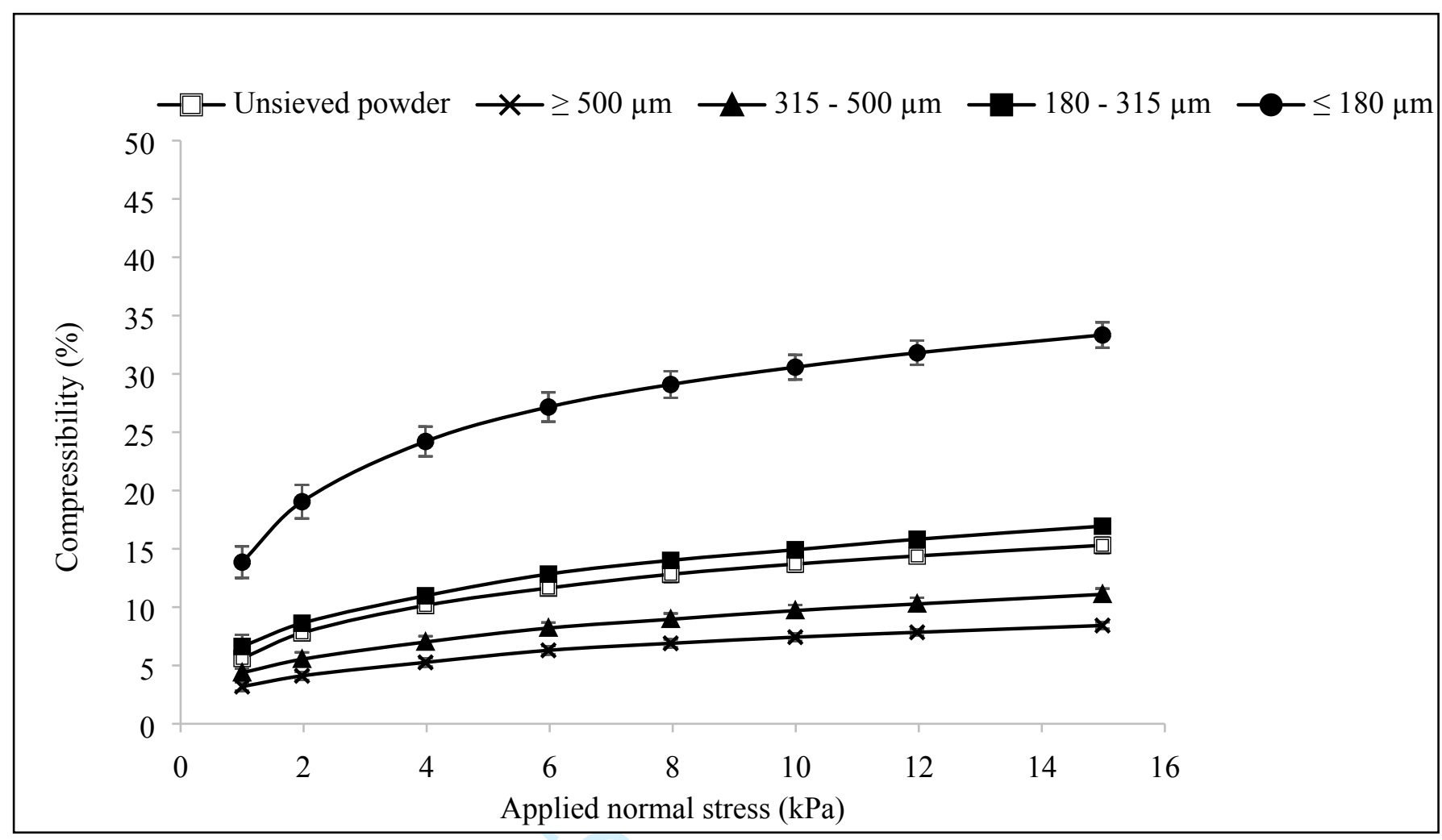

Figure 5: Compressibility of the different granulometric classes and unsieved sample of okra seed powders obtained by milling at $6000 \mathrm{rpm}$. Error bars represent standard deviations; some were smaller than the marker size and thus not visible. 


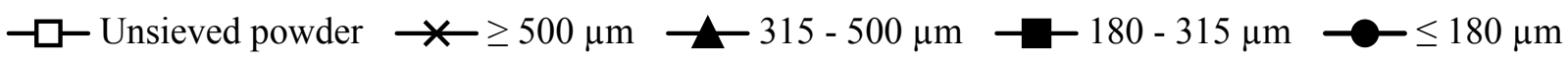

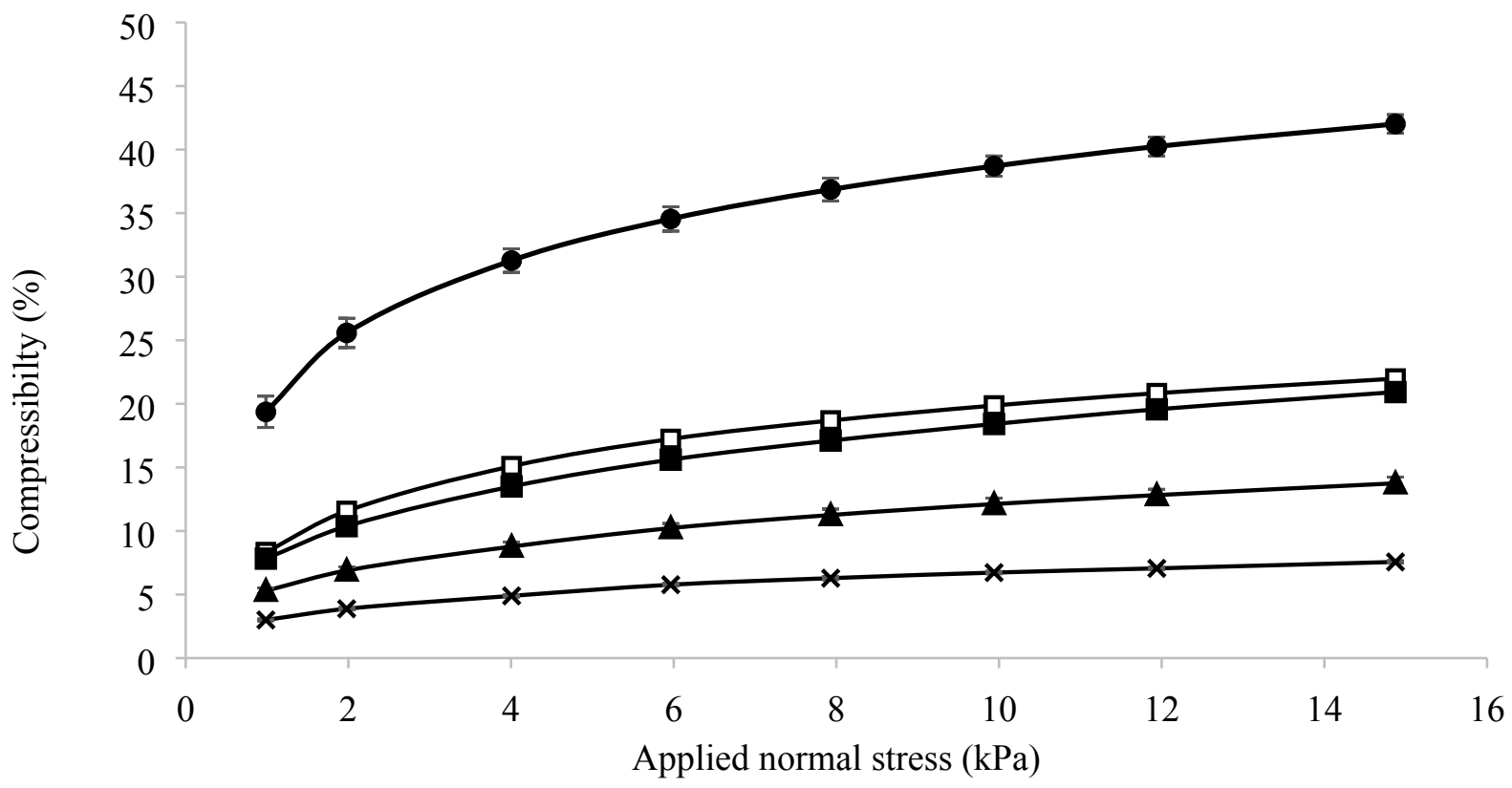

Figure 6: Compressibility of the different granulometric classes and unsieved sample of okra seed powders obtained by milling at $12000 \mathrm{rpm}$. Error bars represent standard deviations; some were smaller than the marker size and thus not visible. 


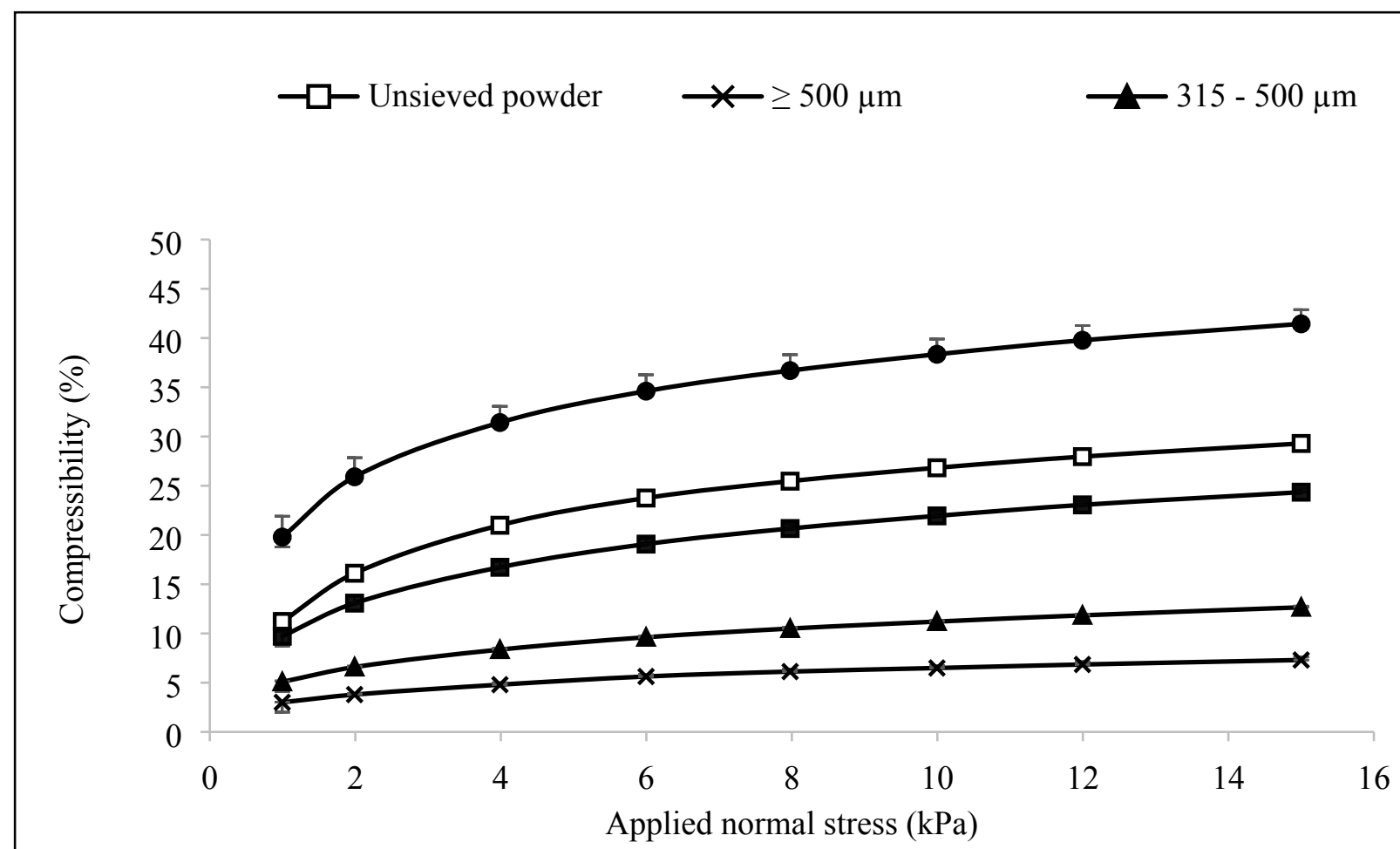

Figure 7: Compressibility of the different granulometric classes and unsieved sample of okra seed powders obtained by milling at $18000 \mathrm{rpm}$. Error bars represent standard deviations; some were smaller than the marker size and thus not visible. 


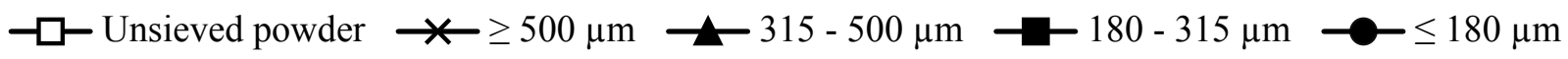

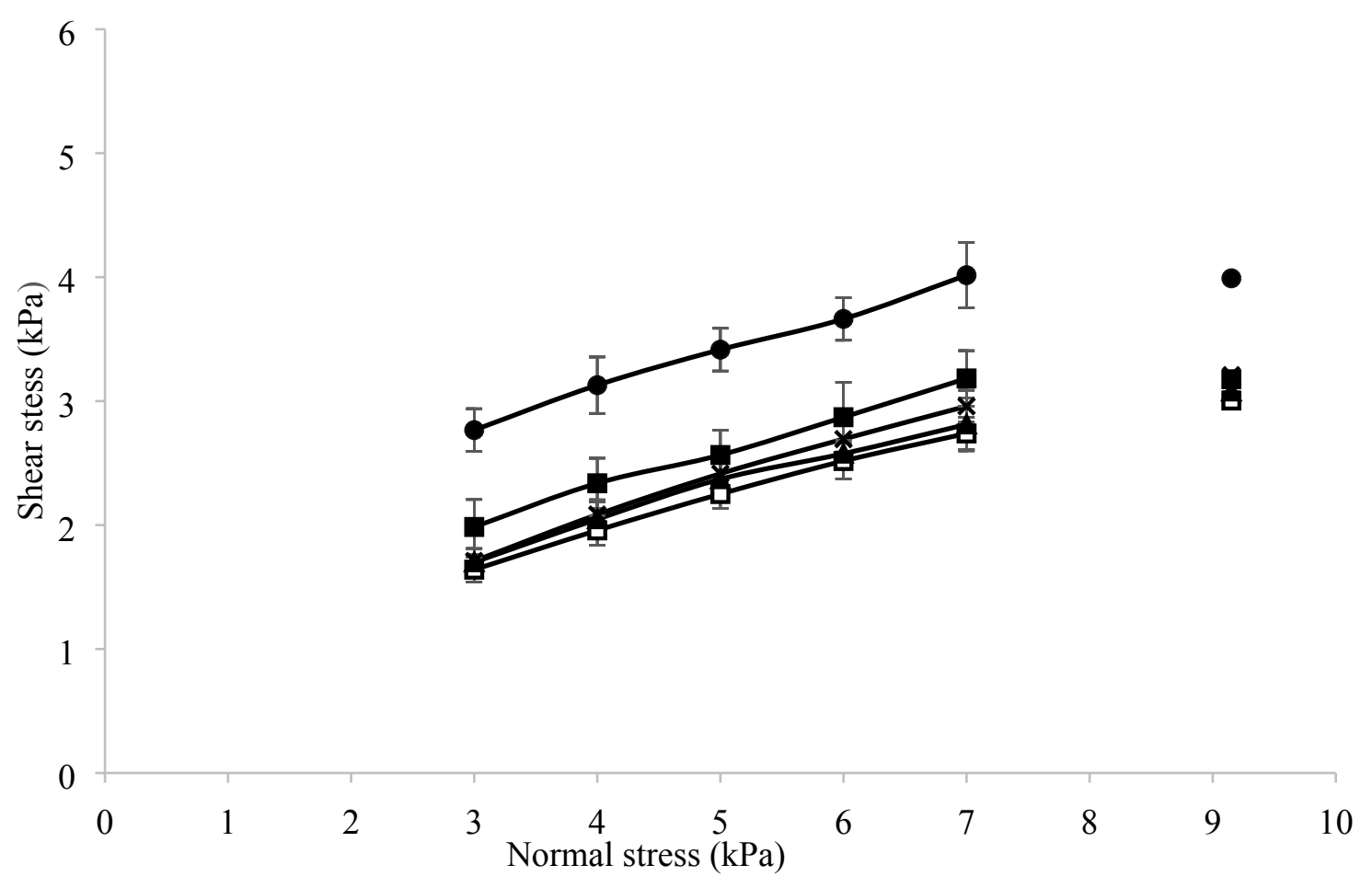

Figure 8: Shear test curve obtained after pre-shear at $9 \mathrm{kPa}$ normal stress for the different granulometric classes and unsieved sample of okra seed powders obtained by milling at 6000 rpm. Error bars represent standard deviations; some were smaller than the marker size and thus not visible. 
$\neg \square$ Unsieved powder $\rightarrow \geq 500 \mu \mathrm{m} \longrightarrow 315-500 \mu \mathrm{m} \rightarrow-180-315 \mu \mathrm{m} \rightarrow-\leq 180 \mu \mathrm{m}$

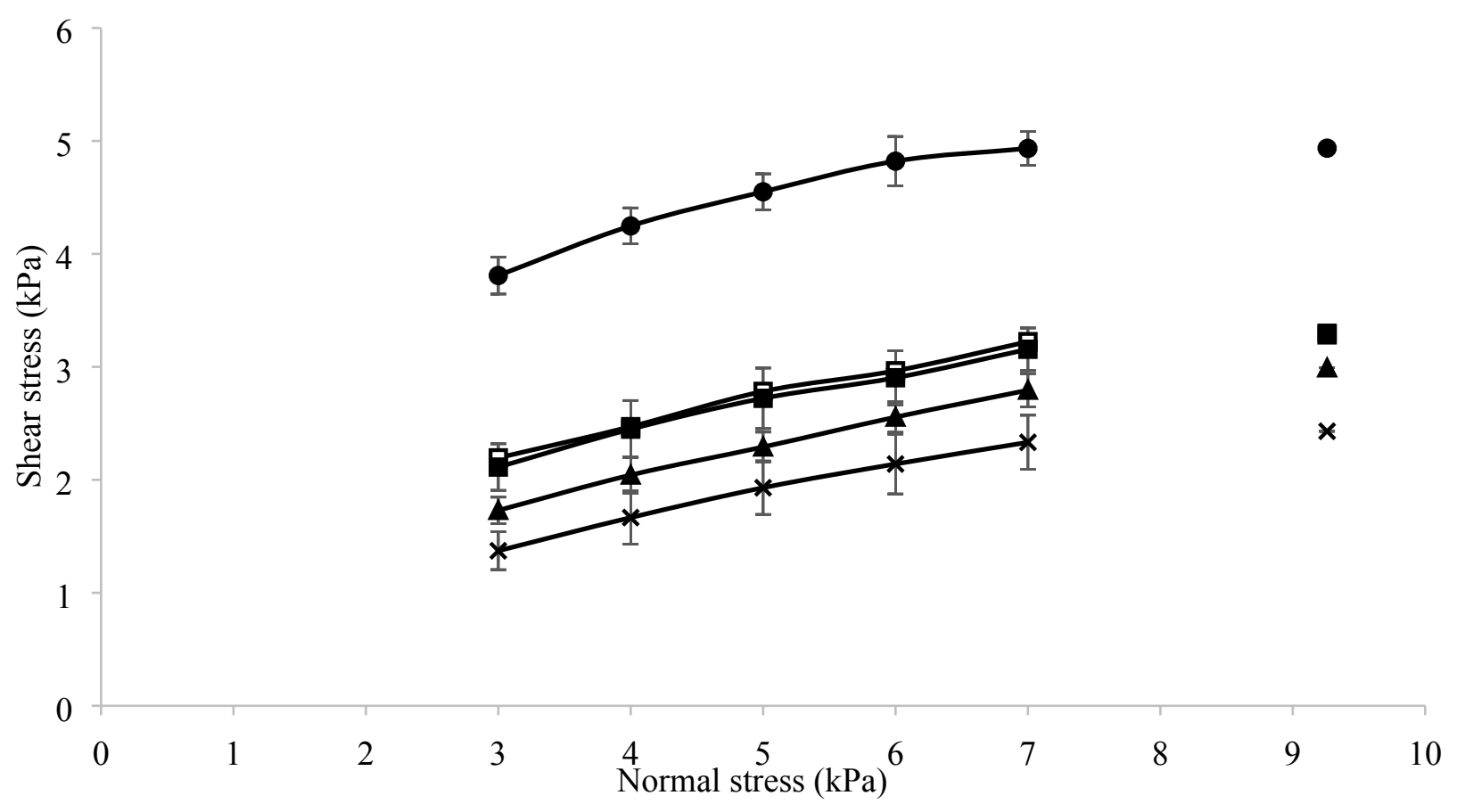

Figure 9: Shear test curve obtained after pre-shear at $9 \mathrm{kPa}$ normal stress for the different granulometric classes and unsieved sample of okra seed powders obtained by milling at 12 $000 \mathrm{rpm}$. Error bars represent standard deviations; some were smaller than the marker size and thus not visible. 


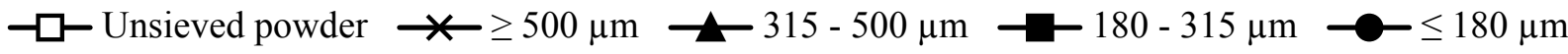

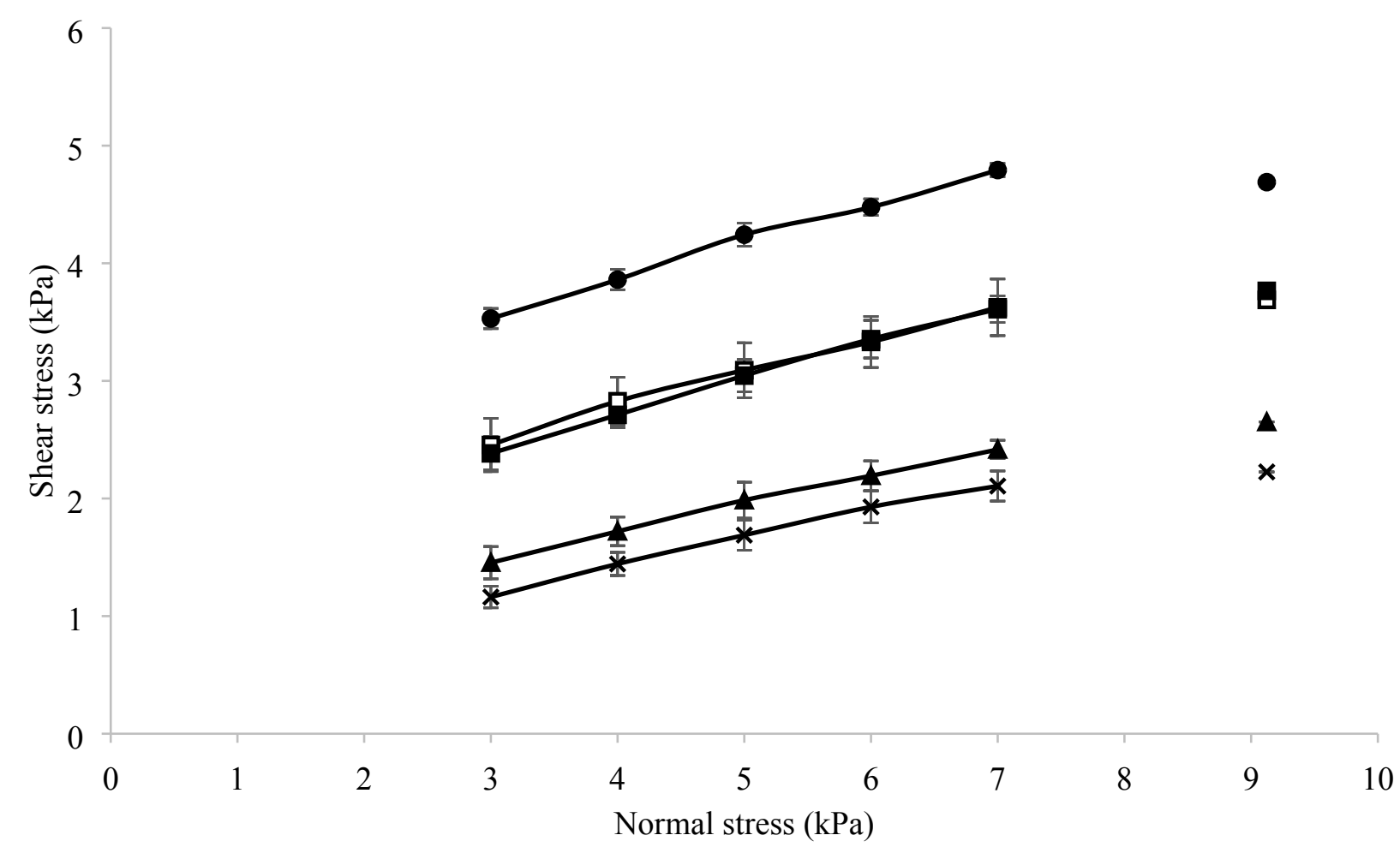

Figure 10: Shear test curve obtained after pre-shear at $9 \mathrm{kPa}$ normal stress for the different granulometric classes and unsieved sample of okra seed powders obtained by milling at 18 $000 \mathrm{rpm}$. Error bars represent standard deviations; some were smaller than the marker size and thus not visible. 
Table 1: Sieved masses and mass fractions of the different granulometric classes and unsieved powders of okra seed powders obtained at 6000 , 12000 , and $18000 \mathrm{rpm}$ milling speed.

\begin{tabular}{|l|l|l|l|l|l|l|}
\hline \multirow{2}{*}{ Milling speed (rpm) } & \multicolumn{2}{|c|}{6000} & & \multicolumn{2}{c|}{12000} & \multicolumn{2}{c|}{1800} \\
\hline Granulometric class & Sieved mass (g) & Mass yield (\%) & Sieved mass (g) & Mass yield (\%) & Sieved mass (g) & Mass yield (\%) \\
& & & & & & \\
\hline$\geq 500 \mu \mathrm{m}$ & 317.53 & 59.13 & 164.18 & 50.26 & 86.83 & 42.47 \\
\hline $315-500 \mu \mathrm{m}$ & 101.05 & 18.82 & 52.34 & 16.02 & 41.75 & 20.42 \\
\hline $180-315 \mu \mathrm{m}$ & 51.16 & 9.53 & 44.68 & 13.68 & 46.32 & 22.66 \\
\hline$\leq 180 \mu \mathrm{m}$ & 67.26 & 12.52 & 65.44 & 20.04 & 29.54 & 14.45 \\
\hline Unsieved powder (total) & 537.00 & 100.00 & 326.64 & 100.00 & 204.44 & 100.00 \\
\hline
\end{tabular}


Table 2: Granulometric parameters of the different granulometric classes and unsieved samples of okra seed powders obtained at 6000,12000 , and $18000 \mathrm{rpm}$ milling speed.

\begin{tabular}{|c|c|c|c|c|}
\hline Milling speed (rpm) & \multicolumn{4}{|c|}{6000} \\
\hline Granulometric classes & $\mathrm{d} 10(\mu \mathrm{m})$ & $\mathrm{d} 50(\mu \mathrm{m})$ & $\mathrm{d} 90(\mu \mathrm{m})$ & Span (-) \\
\hline$\geq 500 \mu \mathrm{m}$ & $589.33 \pm 18.50^{\mathrm{d}}$ & $1100.00 \pm 43.59^{\mathrm{e}}$ & $2173.33 \pm 73.71^{\mathrm{e}}$ & $1.44 \pm 0.02^{\mathrm{c}}$ \\
\hline $315-500 \mu \mathrm{m}$ & $326.67 \pm 6.03^{c}$ & $498.33 \pm 2.52^{c}$ & $745.33 \pm 2.52^{\mathrm{c}}$ & $0.87 \pm 0.03^{\mathrm{a}}$ \\
\hline $180-315 \mu \mathrm{m}$ & $152.00 \pm 1.00^{\mathrm{b}}$ & $257.00 \pm 1.00^{\mathrm{b}}$ & $406.00 \pm 1.00^{b}$ & $0.97 \pm 0.01^{b}$ \\
\hline$\leq 180 \mu \mathrm{m}$ & $23.10 \pm 0.20^{\mathrm{a}}$ & $85.30 \pm 0.61^{\mathrm{a}}$ & $181.33 \pm 0.58^{\mathrm{a}}$ & $1.87 \pm 0.01^{\mathrm{d}}$ \\
\hline Unsieved powder & $141.00 \pm 7.81^{\mathrm{b}}$ & $723.33 \pm 29.96^{\mathrm{d}}$ & $1670.00 \pm 65.57^{\mathrm{d}}$ & $2.11 \pm 0.02^{\mathrm{e}}$ \\
\hline Milling speed (rpm) & \multicolumn{4}{|c|}{12000} \\
\hline Granulometric classes & $\mathrm{d} 10(\mu \mathrm{m})$ & $\mathrm{d} 50(\mu \mathrm{m})$ & $\mathrm{d} 90(\mu \mathrm{m})$ & Span (-) \\
\hline$\geq 500 \mu \mathrm{m}$ & $542.67 \pm 5.69^{\mathrm{e}}$ & $801.33 \pm 25.02^{\mathrm{d}}$ & $1243.33 \pm 75.06^{\mathrm{e}}$ & $0.90 \pm 0.05^{b}$ \\
\hline $315-500 \mu \mathrm{m}$ & $312.00 \pm 1.00^{\mathrm{d}}$ & $463.33 \pm 1.15^{\mathrm{c}}$ & $671.67 \pm 4.93^{\mathrm{c}}$ & $0.78 \pm 0.01^{\mathrm{a}}$ \\
\hline $180-315 \mu \mathrm{m}$ & $165.67 \pm 1.53^{\mathrm{c}}$ & $264.67 \pm 1.53^{\mathrm{b}}$ & $409.33 \pm 9.81^{b}$ & $0.92 \pm 0.03^{b}$ \\
\hline$\leq 180 \mu \mathrm{m}$ & $21.90 \pm 0.10^{\mathrm{a}}$ & $75.60 \pm 2.84^{\mathrm{a}}$ & $167.33 \pm 6.35^{\mathrm{a}}$ & $1.95 \pm 0.06^{\mathrm{c}}$ \\
\hline Unsieved powder & $52.93 \pm 0.58^{b}$ & $457.67 \pm 5.13^{\mathrm{c}}$ & $983.00 \pm 7.81^{\mathrm{d}}$ & $2.03 \pm 0.01^{\mathrm{c}}$ \\
\hline Milling speed (rpm) & \multicolumn{4}{|c|}{18000} \\
\hline Granulometric classes & $\mathrm{d} 10(\mu \mathrm{m})$ & $\mathrm{d} 50(\mu \mathrm{m})$ & $\mathrm{d} 90(\mu \mathrm{m})$ & Span (-) \\
\hline$\geq 500 \mu \mathrm{m}$ & $527.67 \pm 4.73^{\mathrm{e}}$ & $781.00 \pm 14.18^{\mathrm{e}}$ & $1186.67 \pm 37.86^{\mathrm{d}}$ & $0.84 \pm 0.02^{b}$ \\
\hline $315-500 \mu \mathrm{m}$ & $290.00 \pm 4.36^{\mathrm{d}}$ & $442.67 \pm 12.86^{\mathrm{d}}$ & $644.67 \pm 25.93^{\mathrm{c}}$ & $0.80 \pm 0.02^{b}$ \\
\hline $180-315 \mu \mathrm{m}$ & $37.40 \pm 0.17^{\mathrm{c}}$ & $181.00 \pm 0.00^{\mathrm{b}}$ & $332.67 \pm 2.08^{\mathrm{b}}$ & $0.48 \pm 0.01^{\mathrm{a}}$ \\
\hline$\leq 180 \mu \mathrm{m}$ & $17.83 \pm 0.25^{\mathrm{a}}$ & $52.13 \pm 0.65^{\mathrm{a}}$ & $149.33 \pm 1.53^{\mathrm{a}}$ & $0.77 \pm 0.01^{b}$ \\
\hline Unsieved powder & $25.70 \pm 0.36^{\mathrm{b}}$ & $228.67 \pm 7.51^{\mathrm{c}}$ & $702.67 \pm 55.77^{\mathrm{c}}$ & $2.96 \pm 0.16^{\mathrm{c}}$ \\
\hline
\end{tabular}

For powder results at each milling speed separately, means \pm standard deviations followed by the same superscripted letters in the same column were not significantly different at $\mathrm{p}<0.05$ according to Tukey's HSD test. 
Table 3: Proximate composition (contents in moisture, lipids, proteins, ash, carbohydrates on wet basis) of the different granulometric classes and unsieved powders of okra seeds.

\begin{tabular}{|c|c|c|c|c|c|c|}
\hline Milling speed (rpm) & \multicolumn{6}{|c|}{6000} \\
\hline Powder sample & Unsieved powder & $\leq 180 \mu \mathrm{m}$ & $180-315 \mu \mathrm{m}$ & $315-500 \mu \mathrm{m}$ & $\geq 500 \mu \mathrm{m}$ & Unsieved powder [3] \\
\hline Moisture $(\%(w / w))$ & $11.10 \pm 0.07^{\mathrm{b}}$ & $9.59 \pm 0.12^{a}$ & $9.01 \pm 0.67^{\mathrm{a}}$ & $9.21 \pm 0.11^{\mathrm{a}}$ & $12.07 \pm 0.05^{\mathrm{c}}$ & $9.45 \pm 0.80$ \\
\hline Fat $(\%(w / w))$ & $12.05 \pm 0.07^{b}$ & $23.61 \pm 0.01^{\mathrm{c}}$ & $23.14 \pm 0.43^{\mathrm{c}}$ & $23.34 \pm 0.02^{\mathrm{c}}$ & $7.63 \pm 0.20^{\mathrm{a}}$ & $24.90 \pm 0.55$ \\
\hline Proteins $(\%(\mathrm{w} / \mathrm{w}))$ & $16.45 \pm 0.74^{\mathrm{b}}$ & $32.08 \pm 0.81^{\mathrm{d}}$ & $30.07 \pm 1.19^{\mathrm{cd}}$ & $28.77 \pm 0.29^{c}$ & $10.77 \pm 0.62^{\mathrm{a}}$ & $24.85 \pm 1.50$ \\
\hline Carbohydrates $(\%(\mathrm{w} / \mathrm{w}))$ & $55.44 \pm 0.82^{b}$ & $28.33 \pm 0.77^{a}$ & $30.28 \pm 1.63^{\mathrm{a}}$ & $32.12 \pm 0.42^{\mathrm{a}}$ & $68.70 \pm 8.04^{\mathrm{c}}$ & $36.83 \pm 1.78$ \\
\hline $\operatorname{Ash}(\%(\mathrm{w} / \mathrm{w}))$ & $4.96 \pm 0.04^{\mathrm{a}}$ & $6.39 \pm 0.01^{b}$ & $7.00 \pm 0.66^{b}$ & $6.56 \pm 0.07^{b}$ & $4.21 \pm 0.46^{\mathrm{a}}$ & $5.68 \pm 0.10$ \\
\hline Milling speed (rpm) & \multicolumn{6}{|c|}{12000} \\
\hline Powder sample & Unsieved powder & $\leq 180 \mu \mathrm{m}$ & $180-315 \mu \mathrm{m}$ & $315-500 \mu \mathrm{m}$ & $\geq 500 \mu \mathrm{m}$ & Unsieved powder [3] \\
\hline Moisture $(\%(w / w))$ & $11.27 \pm 0.08^{c}$ & $9.15 \pm 0.10^{\mathrm{b}}$ & $8.61 \pm 0.08^{a}$ & $9.22 \pm 0.05^{b}$ & $11.79 \pm 0.06^{\mathrm{d}}$ & $9.45 \pm 0.80$ \\
\hline Fat $(\%(w / w))$ & $13.71 \pm 0.89^{\mathrm{b}}$ & $26.69 \pm 0.54^{\mathrm{e}}$ & $23.40 \pm 0.27^{\mathrm{d}}$ & $19.21 \pm 0.22^{c}$ & $5.18 \pm 0.17^{\mathrm{a}}$ & $24.90 \pm 0.55$ \\
\hline Proteins $(\%(\mathrm{w} / \mathrm{w}))$ & $17.04 \pm 0.31^{\mathrm{b}}$ & $34.35 \pm 0.62^{\mathrm{e}}$ & $30.61 \pm 0.27^{\mathrm{d}}$ & $27.63 \pm 1.12^{c}$ & $7.84 \pm 0.30^{\mathrm{a}}$ & $24.85 \pm 1.50$ \\
\hline Carbohydrates $(\%(\mathrm{w} / \mathrm{w}))$ & $51.01 \pm 0.35^{\mathrm{d}}$ & $18.79 \pm 0.68^{\mathrm{a}}$ & $30.53 \pm 0.20^{\mathrm{b}}$ & $37.58 \pm 1.19^{c}$ & $70.33 \pm 0.35^{\mathrm{e}}$ & $36.83 \pm 1.78$ \\
\hline $\operatorname{Ash}(\%(\mathrm{w} / \mathrm{w}))$ & $5.12 \pm 0.15^{b}$ & $6.73 \pm 0.04^{\mathrm{d}}$ & $6.23 \pm 0.04^{c}$ & $5.83 \pm 0.09^{c}$ & $4.09 \pm 0.35^{\mathrm{a}}$ & $5.68 \pm 0.10$ \\
\hline Milling speed (rpm) & \multicolumn{6}{|c|}{18000} \\
\hline Powder sample & Unsieved powder & $\leq 180 \mu \mathrm{m}$ & $180-315 \mu \mathrm{m}$ & $315-500 \mu \mathrm{m}$ & $\geq 500 \mu \mathrm{m}$ & Unsieved powder [3] \\
\hline Moisture $(\%(\mathrm{w} / \mathrm{w}))$ & $10.69 \pm 0.09^{\mathrm{c}}$ & $9.56 \pm 0.08^{\mathrm{a}}$ & $10.15 \pm 0.02^{\mathrm{b}}$ & $11.32 \pm 0.06^{\mathrm{d}}$ & $13.20 \pm 0.17^{\mathrm{e}}$ & $9.45 \pm 0.80$ \\
\hline Fat $(\%(w / w))$ & $14.57 \pm 0.69^{\mathrm{c}}$ & $27.80 \pm 0.51^{\mathrm{e}}$ & $23.51 \pm 0.08^{\mathrm{d}}$ & $12.17 \pm 0.15^{b}$ & $3.43 \pm 0.43^{\mathrm{a}}$ & $24.90 \pm 0.55$ \\
\hline Proteins $(\%(\mathrm{w} / \mathrm{w}))$ & $18.37 \pm 0.12^{b}$ & $35.01 \pm 0.26^{\mathrm{e}}$ & $28.62 \pm 0.24^{\mathrm{d}}$ & $19.72 \pm 0.72^{c}$ & $5.83 \pm 0.53^{\mathrm{a}}$ & $24.85 \pm 1.50$ \\
\hline Carbohydrates $(\%(\mathrm{w} / \mathrm{w}))$ & $50.99 \pm 1.23^{\mathrm{c}}$ & $24.73 \pm 0.68^{a}$ & $33.33 \pm 0.88^{b}$ & $52.94 \pm 2.52^{\mathrm{c}}$ & $73.19 \pm 0.76^{\mathrm{d}}$ & $36.83 \pm 1.78$ \\
\hline $\operatorname{Ash}(\%(\mathrm{w} / \mathrm{w}))$ & $5.18 \pm 0.04^{\mathrm{c}}$ & $6.80 \pm 0.01^{\mathrm{e}}$ & $5.94 \pm 0.06^{\mathrm{d}}$ & $4.39 \pm 0.16^{\mathrm{b}}$ & $3.75 \pm 0.28^{\mathrm{a}}$ & $5.68 \pm 0.10$ \\
\hline
\end{tabular}


Table 4: Results of stability and compressibility tests for unsieved samples and granulometric classes of okra seed powders produced at 6000,12 000, and $18000 \mathrm{rpm}$ milling speed.

\begin{tabular}{|c|c|c|c|c|c|}
\hline Milling speed & \multicolumn{5}{|c|}{6000} \\
\hline Powder sample & $\begin{array}{l}\text { Unsieved } \\
\text { powder }\end{array}$ & $\leq 180 \mu \mathrm{m}$ & $180-315 \mu \mathrm{m}$ & $\begin{array}{l}315-500 \\
\mu \mathrm{m}\end{array}$ & $\geq 500 \mu \mathrm{m}$ \\
\hline $\mathrm{BFE}(\mathrm{mJ})$ & $285.00 \pm 2.27^{d}$ & $93.12 \pm 2.00^{\mathrm{a}}$ & $\begin{array}{l}164.96 \pm \\
10.12^{\mathrm{b}}\end{array}$ & $\begin{array}{c}197.49 \pm \\
14.34^{\mathrm{c}}\end{array}$ & $265.58 \pm 7.92^{\mathrm{d}}$ \\
\hline $\mathrm{SE}(\mathrm{mJ} / \mathrm{g})$ & $6.70 \pm 0.24^{\mathrm{c}}$ & $5.94 \pm 0.14^{\mathrm{bc}}$ & $4.64 \pm 0.61^{\mathrm{a}}$ & $4.91 \pm 0.31^{\mathrm{ab}}$ & $5.50 \pm 0.50^{\mathrm{ab}}$ \\
\hline $\mathrm{CBD}(\mathrm{g} / \mathrm{mL})$ & $0.53 \pm 0.02^{d}$ & $0.33 \pm 0.01^{\mathrm{a}}$ & $0.44 \pm 0.00^{b}$ & $0.50 \pm 0.01^{\mathrm{c}}$ & $0.58 \pm 0.00^{\mathrm{e}}$ \\
\hline $\mathrm{CD}_{15 \mathrm{kPa}}(\mathrm{g} / \mathrm{mL})$ & $0.63 \pm 0.02^{\mathrm{d}}$ & $0.50 \pm 0.01^{\mathrm{a}}$ & $0.53 \pm 0.00^{\mathrm{b}}$ & $0.57 \pm 0.02^{\mathrm{c}}$ & $0.64 \pm 0.00^{\mathrm{d}}$ \\
\hline $\mathrm{CP}_{15 \mathrm{kPa}}(\%)$ & $15.30 \pm 0.67^{c}$ & $33.34 \pm 1.09^{d}$ & $16.95 \pm 0.00^{c}$ & $11.10 \pm 0.50^{\mathrm{b}}$ & $8.43 \pm 0.28^{\mathrm{a}}$ \\
\hline $\begin{array}{l}\text { Milling speed } \\
\text { (rpm) }\end{array}$ & \multicolumn{5}{|c|}{12000} \\
\hline Powder sample & $\begin{array}{l}\text { Unsieved } \\
\text { powder }\end{array}$ & & $180-315 \mu \mathrm{m}$ & $\begin{array}{c}315-500 \\
\mu \mathrm{m}\end{array}$ & $\geq 500 \mu \mathrm{m}$ \\
\hline $\mathrm{BFE}(\mathrm{mJ})$ & $259.04 \pm 6.43^{c}$ & $89.88 \pm 7.19^{a}$ & $\begin{array}{c}190.37 \pm \\
2.47^{\mathrm{b}} \\
\end{array}$ & $\begin{array}{c}252.10 \pm \\
6.53^{\mathrm{c}}\end{array}$ & $248.57 \pm 7.03^{c}$ \\
\hline $\mathrm{SE}(\mathrm{mJ} / \mathrm{g})$ & $7.08 \pm 0.13^{\mathrm{c}}$ & $7.08 \pm 0.11^{\mathrm{c}}$ & $5.45 \pm 0.07^{b}$ & $5.56 \pm 0.23^{b}$ & $4.50 \pm 0.61^{\mathrm{a}}$ \\
\hline CBD $(\mathrm{g} / \mathrm{mL})$ & $0.53 \pm 0.01^{\mathrm{c}}$ & $0.33 \pm 0.03^{\mathrm{a}}$ & $0.42 \pm 0.01^{b}$ & $0.50 \pm 0.01^{\mathrm{c}}$ & $0.61 \pm 0.02^{d}$ \\
\hline $\mathrm{CD}_{15 \mathrm{kPa}}(\mathrm{g} / \mathrm{mL})$ & $0.67 \pm 0.01^{\mathrm{b}}$ & $0.57 \pm 0.06^{\mathrm{a}}$ & $0.53 \pm 0.00^{\mathrm{a}}$ & $0.57 \pm 0.01^{\mathrm{a}}$ & $0.66 \pm 0.02^{b}$ \\
\hline $\mathrm{CP}_{15 \mathrm{kPa}}(\%)$ & $21.98 \pm 0.18^{\mathrm{c}}$ & $42.01 \pm 0.89^{d}$ & $20.92 \pm 0.62^{c}$ & $13.75 \pm 0.58^{b}$ & $7.56 \pm 0.11^{\mathrm{a}}$ \\
\hline $\begin{array}{l}\text { Milling speed } \\
\text { (rpm) }\end{array}$ & \multicolumn{5}{|c|}{18000} \\
\hline Powder sample & $\begin{array}{l}\text { Unsieved } \\
\text { powder }\end{array}$ & $\leq 180 \mu \mathrm{m}$ & $180-315 \mu \mathrm{m}$ & $\begin{array}{c}315-500 \\
\mu \mathrm{m}\end{array}$ & $\geq 500 \mu \mathrm{m}$ \\
\hline $\mathrm{BFE}(\mathrm{mJ})$ & $219.48 \pm 3.48^{b}$ & $88.09 \pm 17.89^{\mathrm{a}}$ & $\begin{array}{l}204.28 \pm \\
17.54^{\mathrm{b}}\end{array}$ & $\begin{array}{c}311.58 \pm \\
7.16^{\mathrm{c}} \\
\end{array}$ & $299.17 \pm 21.76^{\mathrm{c}}$ \\
\hline $\mathrm{SE}(\mathrm{mJ} / \mathrm{g})$ & $7.12 \pm 0.41^{b}$ & $6.88 \pm 0.61^{b}$ & $6.49 \pm 0.19^{\mathrm{ab}}$ & $6.14 \pm 0.21^{\mathrm{ab}}$ & $5.68 \pm 0.22^{a}$ \\
\hline CBD $(\mathrm{g} / \mathrm{mL})$ & $0.47 \pm 0.00^{\mathrm{c}}$ & $0.33 \pm 0.03^{\mathrm{a}}$ & $0.42 \pm 0.01^{b}$ & $0.51 \pm 0.01^{\mathrm{d}}$ & $0.60 \pm 0.01^{\mathrm{e}}$ \\
\hline $\mathrm{CD}_{15 \mathrm{kPa}}(\mathrm{g} / \mathrm{mL})$ & $0.66 \pm 0.01^{b}$ & $0.56 \pm 0.04^{a}$ & $0.56 \pm 0.01^{\mathrm{a}}$ & $0.59 \pm 0.01^{\mathrm{a}}$ & $0.65 \pm 0.02^{b}$ \\
\hline $\mathrm{CP}_{15 \mathrm{kPa}}(\%)$ & $29.29 \pm 0.74^{\mathrm{d}}$ & $41.44 \pm 1.77^{\mathrm{e}}$ & $24.35 \pm 0.42^{\mathrm{c}}$ & $12.66 \pm 0.16^{\mathrm{b}}$ & $7.31 \pm 0.39^{a}$ \\
\hline
\end{tabular}

Means \pm standard deviations followed by the same superscripted letters in the same row were not significantly different at $\mathrm{p}<0.05$ according to Tukey's HSD test. 
Table 5: Aeration and shear cell test results for unsieved powders and granulometric classes of okra seed powders obtained at 6000,12000 , and $18000 \mathrm{rpm}$ milling speed.

\begin{tabular}{|c|c|c|c|c|c|}
\hline Milling speed (rpm) & \multicolumn{5}{|c|}{6000} \\
\hline Powder sample & $\begin{array}{l}\text { Unsieved } \\
\text { powder }\end{array}$ & $\leq 180 \mu \mathrm{m}$ & $180-315 \mu \mathrm{m}$ & $315-500 \mu \mathrm{m}$ & $\geq 500 \mu \mathrm{m}$ \\
\hline $\begin{array}{l}\text { Aerated energy AE } \\
(\mathrm{mJ})\end{array}$ & $\begin{array}{l}85.77 \pm \\
13.53^{\mathrm{b}}\end{array}$ & $21.12 \pm 2.56^{\mathrm{a}}$ & $44.26 \pm 2.40^{\mathrm{a}}$ & $51.45 \pm 12.88^{a}$ & $\begin{array}{l}108.48 \pm \\
20.79^{b}\end{array}$ \\
\hline Aeration ratio AR (-) & $1.25 \pm 0.07^{\mathrm{a}}$ & $2.53 \pm 0.19^{b}$ & $1.39 \pm 0.13^{\mathrm{a}}$ & $1.16 \pm 0.09^{\mathrm{a}}$ & $1.12 \pm 0.10^{\mathrm{a}}$ \\
\hline Cohesion $(\mathrm{kPa})$ & $0.84 \pm 0.09^{\mathrm{a}}$ & $1.88 \pm 0.18^{b}$ & $1.12 \pm 0.19^{a}$ & $0.92 \pm 0.08^{a}$ & $0.81 \pm 0.10^{\mathrm{a}}$ \\
\hline Flow factor ffc (-) & $5.29 \pm 0.53^{c}$ & $2.41 \pm 0.16^{\mathrm{a}}$ & $3.91 \pm 0.62^{b}$ & $4.88 \pm 0.42^{b c}$ & $5.32 \pm 0.59^{c}$ \\
\hline Milling speed (rpm) & \multicolumn{5}{|c|}{12000} \\
\hline Powder sample & $\begin{array}{l}\text { Unsieved } \\
\text { powder }\end{array}$ & $\leq 180 \mu \mathrm{m}$ & $180-315 \mu \mathrm{m}$ & $315-500 \mu \mathrm{m}$ & $\geq 500 \mu \mathrm{m}$ \\
\hline $\begin{array}{l}\text { Aerated energy AE } \\
(\mathrm{mJ})\end{array}$ & $\begin{array}{l}104.87 \pm \\
26.69^{\mathrm{a}}\end{array}$ & $58.21 \pm 25.21^{\mathrm{a}}$ & $73.12 \pm 9.82^{\mathrm{a}}$ & $80.95 \pm 11.52^{\mathrm{a}}$ & $64.62 \pm 1.39^{a}$ \\
\hline Aeration ratio AR (-) & $1.53 \pm 0.15^{b}$ & $2.14 \pm 0.23^{c}$ & $1.26 \pm 0.03^{\mathrm{ab}}$ & $1.06 \pm 0.01^{\mathrm{a}}$ & $0.99 \pm 0.08^{\mathrm{a}}$ \\
\hline Cohesion $(\mathrm{kPa})$ & $1.45 \pm 0.22^{b}$ & $3.05 \pm 0.19^{c}$ & $1.39 \pm 0.32^{b}$ & $0.96 \pm 0.15^{\mathrm{ab}}$ & $0.69 \pm 0.18^{\mathrm{a}}$ \\
\hline Flow factor ffc $(-)$ & $3.14 \pm 0.59^{\mathrm{ab}}$ & $1.60 \pm 0.09^{\mathrm{a}}$ & $3.34 \pm 0.74^{\mathrm{ab}}$ & $4.65 \pm 0.82^{\mathrm{bc}}$ & $6.44 \pm 2.42^{\mathrm{c}}$ \\
\hline Milling speed (rpm) & \multicolumn{5}{|c|}{18000} \\
\hline Powder sample & $\begin{array}{l}\text { Unsieved } \\
\text { powder }\end{array}$ & $\leq 180 \mu \mathrm{m}$ & $180-315 \mu \mathrm{m}$ & $315-500 \mu \mathrm{m}$ & $\geq 500 \mu \mathrm{m}$ \\
\hline $\begin{array}{l}\text { Aerated energy AE } \\
(\mathrm{mJ})\end{array}$ & $75.25 \pm 1.37^{b}$ & $31.91 \pm 3.95^{\mathrm{a}}$ & $56.05 \pm 18.34^{\mathrm{ab}}$ & $76.50 \pm 8.16^{b}$ & $61.15 \pm 5.81^{\mathrm{b}}$ \\
\hline & & & $n_{2}$ & & \\
\hline Aeration ratio AR (-) & $1.47 \pm 0.04^{\mathrm{a}}$ & $2.09 \pm 0.13^{b}$ & $1.38 \pm 0.30^{\mathrm{a}}$ & $1.18 \pm 0.03^{\mathrm{a}}$ & $1.09 \pm 0.20^{\mathrm{a}}$ \\
\hline Cohesion $(\mathrm{kPa})$ & $1.64 \pm 0.26^{b}$ & $2.61 \pm 0.20^{c}$ & $1.48 \pm 0.17^{\mathrm{b}}$ & $0.76 \pm 0.22^{\mathrm{a}}$ & $0.48 \pm 0.11^{\mathrm{a}}$ \\
\hline Flow factor ffc (-) & $2.80 \pm 0.40^{\mathrm{a}}$ & $1.80 \pm 0.05^{\mathrm{a}}$ & $3.06 \pm 0.28^{a}$ & $6.11 \pm 1.24^{b}$ & $8.98 \pm 2.09^{b}$ \\
\hline
\end{tabular}

Means \pm standard deviations followed by the same superscripted letters in the same row were not significantly different at $\mathrm{p}<0.05$ according to Tukey's HSD test. 


\section{Conflict of interests:}

The authors declare that they have no conflict of interest.

Authors e-mail adresses: idrissmiganehwaiss@gmail.com ; jeremy.petit@univ-lorraine.fr ; kimbothluc@gmail.com; fatouma_abdoulatif@yahoo.fr; joel.scher@univ-lorraine.fr; louis.matos@umng.cg; aminazahramoussa@gmail.com 


\section{Ethics statements:}

No experiment was performed on humans or animals. So, ethics approval was not required for this research. 
Data Availability Statement:

Research data are not shared. 
The authors wish to thank the reviewers for their new helpful comments. Detailed point-by-point response can be found hereafter, with reviewer comments in black (line numbers associated with reviewer comments correspond to submitted manuscript) and answers in blue (line numbers related to manuscript revision correspond to revised manuscript). In revised manuscript, additions were performed in blue and deletions in red crossed words.

\section{Reviewer \#1}

The revision is satisfactory.

Thank you for your work in reviewing the manuscript.

\section{Reviewer \#2}

Although the work presents interesting, it is quite hard to understand the paper due to poor communication. therefore i couldn't identify the main goal of this paper.Overall, this is not a well-written manuscript. There were no sufficient information about the previous study findings presented for readers to follow the present study rationale and procedures. Finally, I recommend that the paper should not be accepted for the publication in the present from.

Thank you for your work in reviewing the manuscript, the authors have tried to take into account these remarks in the second revised manuscript.

- L47: this sentence is not required it is repeating

The sentence in 141-43 indicates that okra (in general, i.e. all plant parts being considered) provides carbohydrates, protein, fat, minerals, and vitamins that are usually deficient in staple foods. The sentence in 147 concerns more specifically okra seeds, which is the studied material. Thus, it was decided to keep this sentence giving further information about the composition of okra seeds.

L49-50: Seeds are rich in proteins (45\%) and lipids (34\%), thus use as a food for a malnutrition children in Nigeria. (reference).

In order to reduce the length of this sentence, the authors preferred to delete "classifying is as a nutrient-rich plant". Also, "A research program initiated by Nigeria" was corrected by "A Nigerian research program".

- L52-54: rewrite, English is not good 
This sentence was rewritten (cf. I51-53).

- L56: this sentence is not clear

Indeed, this convoluted sentence was removed.

- L58: you should discuss about this before you discuss the aim of this paper? you need to explain why you need to study this and the importance of this area and its relationship to human health as well as to okra

The link between nutritional quality and granulometric class has been added in I55-61, which permits to better introduce the aim of the study. The link with human health (food supplements) was added in 164-65.

- L59: this sente4nce and previous sentence has a big jump

"flow properties" was removed as it was not introduced previously. The link with the distribution of nutritional compounds within granulometric classes was made through the production of food supplements (cf. 164-65). The reason for studying also flow properties has been developed in 174-79.

- L64: not clear why

Indeed, this should now be clearer with the mention of "food supplements" in 164-65.

- L66: I what are the bioactive compounds you are going to extract not clear.

Indeed, this was out of the scope of the study, and "bioactive" as "replaced" by "nutritional" (cf. 167-68).

- L67: if you introduce new cofounders you need to explain them.

The authors did not understand this comment, nevertheless this sentence was out of the scope of the study and it was removed.

L68: I can't understand your English.

This sentence was deleted.

L70: not clear

The authors did not understand what is not clear in this sentence, and thus it as kept unchanged.

L73: not clear

This sentence was corrected in 183-84. 
L78: your introduction and the purpose is not matching rewrite.

With changes made in the second revised manuscript, the authors hope that the link between bibliographical data and study aim is now clearer.

\section{L92-93: rewrite}

The authors did not understand why this sentence should be rewritten, so it was kept unchanged.

L94: it is important do proof reading of your paper

This sentence appears clear enough, so the authors do not understand why this comment was formulated by reviewer \#2. Maybe the fact that the sentence was justified and not aligned to the left? This was changed in I105.

L98: this sentence is too long rewrite

The authors did not find that this sentence is too long (42 words, 245 characters including spaces), and only one idea is presented in this sentence, so it was decided to keep this sentence unchanged.

L101: what do you mean by issued

This was corrected by "resulting from"

L104: you English is very poor so hard to understand.

The authors really did not understand this comment, as concerned sentence cannot be clearer.

\section{L225-226: I can't understand what you mean by two populations.}

It is very classical to talk about particle populations when discussing particle size distribution results. A particle population gathers all particles having similar characteristics, like size in the case of granulometric analysis. See here for instance: http://www-odp.tamu.edu/publications/178_SR/Volume/CHAPTERS/SR178_24.PDF 